\title{
Palaeoclimatic studies in South Shetland Islands, Antarctica, based on numerous stratigraphic variables in lake sediments
}

\author{
Svante Björck ${ }^{1}$, Hannelore Håkansson ${ }^{1}$, Siv Olsson ${ }^{1}$, Lena Barnekow ${ }^{1}$ \& Jan Janssens ${ }^{2}$ \\ ${ }^{1}$ Department of Quaternary Geology, Lund University, Tornav. 13, S-223 63 Lund, Sweden; ${ }^{2}$ Department \\ of Ecology, Evolution and Behaviour, University of Minnesota, 109 Zoology, 318 Church Street S.E., \\ Minneapolis, MN 55455, USA
}

Received 5 January 1993; accepted 24 March 1993

Key words: lake sediments, diatoms, spores, tephra, mineralogy, sediment chemistry, mosses, multivariate analysis, palaeoclimate, holocene, Livingston Island, Antarctica

\begin{abstract}
The hitherto longest found lake sediment sequence on Byers Peninsula, Livingston Island, South Shetland Islands, was analysed with respect to lithology, chronology, diatoms, Pediastrum, pollen and spores, mosses, mineralogy, and sediment chemistry. During the $c a .5000$ year long development the sediments were influenced by frequent tephra fall-outs. This volcanic impact played a major role in the lake's history during two periods, 4700-4600 and 2800-2500 BP, but was of importance during the lake's entire history with considerable influence on many of the palaeoenvironmentally significant indicators. The large and complex data set was analysed and zonated with different types of multivariate analysis. This resulted in a subdivision of the sequence into 8 time periods and 21 variables. Redundancy analysis (RDA) of this data set, both without and with the tephra periods, and with 4-6 of the variables as explanatory environmental variables, reveal that climatic/environmental signals are detectable. The palaeoclimatic picture that emerged out of the tephra 'noise' suggests that the first 100 years were characterized by mild, humid conditions. This was followed by a less mild and humid climate until $c a .4000 \mathrm{BP}$ when a gradual warming seems to have started, coupled with increased humidity. These mild and humid conditions seem to have reached an optimum slightly after 3000 BP. At ca. $2500 \mathrm{BP}$ a distinct climatic deterioration occurred with colder and drier conditions and long seasons with ice cover. This arid, cold phase probably reached its optimum conditions at $c a .1500 \mathrm{BP}$, when slightly warmer conditions might have prevailed for a while. Except for the modern sample with rather mild climate, the last 1400 years seem to have been fairly arid and cold, and the effects of the frequent volcanic activity during this period is only vaguely seen in the records.
\end{abstract}

\section{Introduction}

Only recently have researchers begun to use stratigraphic studies of lake sediments in the Antarctic Peninsula region to evaluate Holocene en- vironmental and climatic changes (Tatur \& del Valle, 1986; Mäusbacher et al., 1989; Zale \& Karlén, 1989; Matthies et al., 1990; Schmidt et al., 1990; Björck et al., 1991a; Mäusbacher 1991). Previous attempts have indicated that 
these types of studies have the greatest potential to describe and analyse the Holocene terrestrial environmental history of this part of the world.

Byers Peninsula on Livingston Island is probably the area in Antarctica that has the highest concentration of lakes. The lakes have also proven to contain fairly thick sediments (Björck et al., 1991a) and tephra layers that can be used for correlations and datings (Björck et al., 1991b). These type of time-markers would be perfect for lake level studies, with transects from the shore out to the deeper parts (cf. Digerfeldt, 1988); but because the latter are mostly shallow and flatbottomed, such studies are not feasible.

Our first lake sediment study from this region (Björck et al., 1991a) was a pilot-study to evaluate the possibilities for performing palaeoenvironmental investigations in the Antarctic environment. Since the results were promising, we decided to carry out a wide variety of detailed stratigraphic studies of the hitherto longest found lake sediment sequence on Byers Peninsula.

\section{Area of investigation}

\section{Geography, climate and vegetation}

Within the South Shetland Islands, Livingston Island is the second largest of $c a .10$ more-or-less large islands. It is situated $c a$. $150 \mathrm{~km}$ westnorthwest of the northernmost tip of the Antarctic Peninsula (Fig. 1). Except for Byers Peninsula (Fig. 2) most of the island is covered by glaciers, of which the Rotch Ice Dome borders the peninsula in the east. Apart from the northwestern part of the peninsula, which reaches a maximum of $268 \mathrm{~m}$ above sea level, few areas reach higher than $100 \mathrm{~m}$. Exceptions are a few volcanic plugs of which Chester Cone in the central part of the peninsula is the highest $(193 \mathrm{~m})$ and most prominent feature. The main part of the peninsula forms a $c a .40 \mathrm{~km}^{2}$ large undissected, $85-100 \mathrm{~m}$ high, inland platform with an irregularly undulating topography. On the platform margins is a $30-50 \mathrm{~m}$ platform gently sloping seaward. Further down follow the 11-17 $\mathrm{m}$ and the sea level platforms.

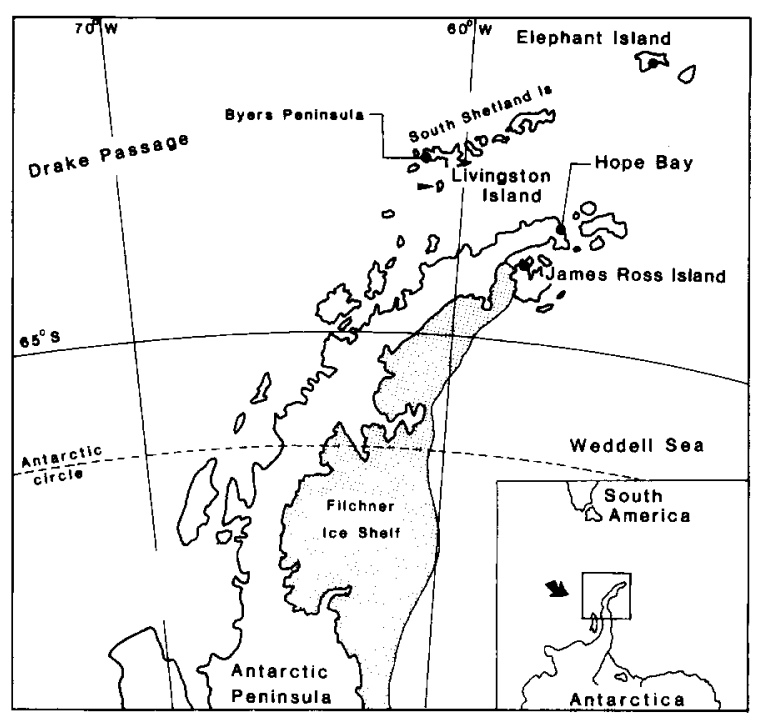

Fig. 1. A map of the Antarctic Peninsula and the South Shetland Islands. The dots indicate sites, including Byers Peninsula on Livingston Island, on which the preliminary regional tephrochronology (Björck et al. 1991b) is based. The position of the Peninsula in relation to South America is indicated on the inserted map.

According to a 21-year long (1947-1967) meteorological record (Orvig, 1970) from nearby

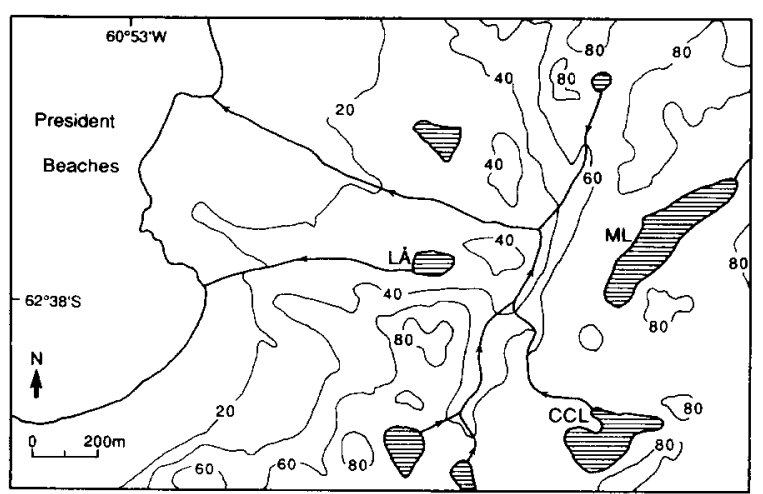

Fig. 2. The study area in the westernmost part of Byers Peninsula indicated with a dot in Fig. 1. 'Lake Åsa' (LA) is situated in the middle of the map. Two other lakes studied, Midge Lake (ML) and Chester Cone Lake (CCL), are also shown. The contour lines with $20 \mathrm{~m}$ equidistance originate from the Spanish project: 'El Cuaternario de Islas Shetland del Sur. Evolucion geomorfologia, historia glaciar y levantamients reciente'. 
Deception Island, January is the mildest and July the coldest month with daily mean temperatures of $+1.4^{\circ} \mathrm{C}$ and $-8^{\circ} \mathrm{C}$, respectively. Between 1948 and 1956 an annual precipitation of $398 \mathrm{~mm}$ was measured, but it is known that precipitation rates vary considerably within the region.

The inland part of Byers Peninsula is almost unvegetated. There are, however, locations where mosses and lichens occur, e.g. on wet valley floors, drained slopes, dry soils, and on rock surfaces. Along the low-lying coastal areas, like President Beaches in the west and South Beaches in the south, the nutrient supplies from the rich fauna and the locally advantageous climate create a much richer vegetation. Carpets of mosses along the beaches are dominated by Drepanocladus uncinatus, and together with the two flowering plants of Antarctica, Deschampsia antarctica and Colobanthus quitensis, lichens, fungi, and liverworts, the vegetation creates patches of green 'oases' in an otherwise rather sterile environment.

\section{Geology and holocene history}

The bedrock mainly consists of Jurassic-Cretaceous plant-bearing shales and sandstones and Upper Jurassic-Lower Cretaceous basalts, basaltic andesites, and volcanic breccias and tuffs (Hobbs, 1968; British Antarctic Survey, 1979). Many different opinions on the Holocene glacial and environmental history of the South Shetland Islands have been presented, but disagreements are more a result of few and insufficient studies than of conflicting data or interpretations. For example John (1972) and Sugden \& Clapperton (1986) conclude that the main deglaciation in this region occurred before 10,000 BP and Clapperton \& Sugden (1980) even assume that the recent glaciation on South Shetland Islands is as extensive as it was $9500 \mathrm{BP}$. Contrasting opinions were expressed by Birkenmajer et al. (1985), Barsch \& Mäusbacher (1986), Tatur \& del Valle (1986), and Björck et al. (1991a, c), whose lake sediment and moss bank studies in different parts of the South Shetland Islands suggest a main midHolocene deglaciation phase. In a later study
Mäusbacher et al. (1989) dated the deglaciation of King George Island to 9000-5000 BP, based on bottom sediment dates in three lakes. By combining many different types of data Hjort et al. (1992) and Ingólfsson et al. (1992) arrive at a slightly different picture: an early deglaciation around $10,000 \mathrm{BP}$, a large glacial readvance around $7000 \mathrm{BP}$ followed by a major deglaciation 6000-5000 BP.

The rather opposing views on the deglaciation age is also reflected in interpretations of the marine limit. For example John (1972) and Birkenmajer (1981) place the marine limit at $50-60 \mathrm{~m}$, while Mäusbacher et al. (1989) put it at $c .18 \mathrm{~m}$. Hjort et al. (1992) conclude that the higher limit might have been formed during the early deglaciation, while the $15-20 \mathrm{~m}$ shoreline is related to the mid-Holocene deglaciation.

Apart from the above described deglaciation histories only a few works (Björck et al. 1991a, c) have focussed on the Holocene palaeoclimate of the South Shetland Islands. Björck et al. (1991a) conclude that a climatic optimum, with milder and more humid conditions, is registered 3200$2700 \mathrm{BP}$ in Midge Lake on Byers Peninsula. This concurs well with the moss bank data on Elephant Island (Björck et al. 1991c). They also think that such humid conditions could have triggered the 3000 BP ice readvance that Barsch \& Mäusbacher (1986) and Mäusbacher et al. (1989) report from King George Island. Schmidt et al. (1990) find evidence of increased allochthonous input between $4700-3200 \mathrm{BP}$, which they relate to a distinct climatic change. Björck et al. (1991a, c) also assume a slightly warmer period at ca. 2000 BP. The Midge Lake data also suggest colder, more continental conditions between 1500 and $500 \mathrm{BP}$, while the moss bank stratigraphy indicates colder conditions at 5500-4300 and 3900-3200 BP and an additional mild period at 4150-3900 BP.

\section{The lake and its surroundings}

The sediment sequence analysed is from a $125 \times 100 \mathrm{~m}$ small lake, here called 'Lake Åsa' 
$\left(62^{\circ} 37^{\prime} 43^{\prime \prime} \mathrm{S}, 61^{\circ} 08^{\prime} 05^{\prime \prime} \mathrm{W}\right)$, situated in the central, westernmost part of Byers Peninsula (Fig. 2). The lake is located $600-700 \mathrm{~m}$ inside the President Beaches. The basin threshold was leveled to $35 \mathrm{~m}$ above sea level, which is well above the mid-Holocene marine limit. An outlet exists in the southwestern corner of this almost square lake, but no inlet. In summer the lake is fed by surface run-off from melting snow, precipitation and melting permafrost. The lake is bordered to the south by a c. $50 \mathrm{~m}$ high hill. The shore in the north and northeast mainly consists of basalt and is $10-20 \mathrm{~m}$ high. A rather gentle slope characterizes the area east of the lake, where probably the largest snow fields accumulate. In the west the shore is not more than $5 \mathrm{~m}$ high. 'Lake Åsa' is a shallow lake, between 0.8 and $1.0 \mathrm{~m}$ deep, but in spite of that the sediment sequence is more than $2 \mathrm{~m}$ thick. The lake is ice-covered at least 8-9 months of the year. Some data on the water chemistry was analysed with the following results (V. Jones: pers. comm.): $\mathrm{pH}=7.6$, Conductivity $=105 \mu \mathrm{S} / \mathrm{cm}, \mathrm{Chl} \mathrm{a}=0.6 \mu \mathrm{g} / \mathrm{l}$, Phae $=0.2 \mu \mathrm{g} / \mathrm{l}$, $\mathrm{NO}_{3}=7.0 \mu \mathrm{g} / \mathrm{l}, \mathrm{TDN}=220.0 \mu \mathrm{g} / \mathrm{l}, \mathrm{Cl}=17.8 \mu \mathrm{g} /$ 1, $\mathrm{Si}=1223.0 \mu \mathrm{g} / \mathrm{l}, \mathrm{TP}=9.0 \mu \mathrm{g} / 1, \mathrm{Na}=6.0 \mu \mathrm{g} / \mathrm{l}$, $\mathrm{Mg}=1.6 \mu \mathrm{g} / \mathrm{l}, \mathrm{K}=0.2 \mu \mathrm{g} / 1, \mathrm{Ca}=2.0 \mu \mathrm{g} / \mathrm{l}$.

Although richer than on the inland platform (where Midge Lake is situated), the vegetation around the lake is very sparse and consists only of scattered finds of mosses and lichens. The densest vegetation on the peninsula is, however, found in a near-by area, inside the President Beaches. The surface run-off from melting snow efficiently erodes soil and vegetation. Patches of aquatic mosses occur on the lake bottom.

\section{Field work}

The field work on 'Lake Åsa' was carried out in March 1989. Apart from reconnaissance corings, two main sequences (with $0.5 \mathrm{~m}$ overlaps) were cored in the middle of the lake with chamber corers of the so-called Russian type, $1 \mathrm{~m}$ long with 5 and $10 \mathrm{~cm}$ diameter, respectively. The corings were carried out from a rubber boat and in order to penetrate through the rather stiff sedi- ments the corers had to be pounded down. The $10 \mathrm{~cm}$ cores were described in detail in the field. A complementary $12 \mathrm{~cm}$ long surface sediment core was sampled with a surface sampler for analysis of recent radionuclides (especially ${ }^{210} \mathrm{~Pb}$ and ${ }^{137} \mathrm{Cs}$ ), and of the microfossil content of the surface sediments. Soils and shore deposits were sampled around the lake.

\section{Laboratory methods and the paleoclimatic impli- cations of some data types}

\section{Sampling, sediment descriptions and datings}

Long core magnetic susceptibility was measured every $2 \mathrm{~cm}$ on the $5 \mathrm{~cm}$ cores. The sampling was also preceded by additional detailed lithologic descriptions of the cores. Because of the many tephra layers, it was fairly easy to correlate between the two sequences.

41 samples for pollen analysis (incl. spores and Pediastrum), 36 samples for diatom analysis, 7 samples for tephra chemistry (Björck et al., 1991b), and 11 levels for ${ }^{14} \mathrm{C}$ datings were taken from the $10 \mathrm{~cm}$ cores, while 43 levels were sampled for analysis of sediment chemistry, grain size, organic carbon, and loss-on-ignition from the 5 $\mathrm{cm}$ cores. In addition, 25 levels from the $10 \mathrm{~cm}$ cores were sampled for moss analyses. The uppermost $6 \mathrm{~cm}$ of the surface sediment were sampled for radionuclides (especially ${ }^{137} \mathrm{Cs},{ }^{210} \mathrm{~Pb}$, and ${ }^{238} \mathrm{Pu}$ ), and the $2.5 \mathrm{~cm}$ level for diatoms, pollen, spores, and Pediastrum. The surface samples were, however, not regarded as reliable with respect to chemical analyses since they had oxidized in the plastic boxes.

The analyses for recent radionuclides were performed by radiation physicists in Lund. The samples were dried and put in test-tubes and analysed with a well type Ge-detector for the determination of ${ }^{210} \mathrm{~Pb}$ and ${ }^{137} \mathrm{Cs}$. The samples were then dissolved, using $\mathrm{HNO}_{3} / \mathrm{HF}$, and analysed for $\mathrm{Pu}$ and Am (Holm 1984). Po was also analysed in order to verify the ${ }^{210} \mathrm{~Pb}$ determinations made by gammaspectrometry.

The radiocarbon dating was carried out at the 
Radiocarbon Dating Laboratory in Lund. All samples were pretreated with $\mathrm{HCl}$ and measured at least $2 \times 1$ day (in some cases $3 \times 1$ and $4 \times 1$ day). The datings of the $\mathrm{NaOH}$-soluble fractions and the Lu-3134 dating were preceded by $\mathrm{NaOH}$ treatments.

The rate of sediment accumulation was estimated for 5 or $10 \mathrm{~cm}$-thick intervals of the sequence from the age/depth curve. Ash-layers were excluded in these calculations, since they most likely represent short episodes of exceptionally high deposition.

The sedimentation rates were used to calculate several parameters in terms of their annual accumulation. In this calculation the bulk density of the sediment was estimated from data on the water content by assuming the density of solids and water to be 2.65 and $1 \mathrm{~g} / \mathrm{cm}^{3}$, respectively. The sedimentation rate may be a good indication of what happened in, and especially around 'Lake Assa'. Periods of high sedimentation rates suggest intense soil erosion with high precipitation (humid/mild) and probably also increased thawing with a thicker active layer.

\section{Grain-size analysis}

A Sedigraph 5000 ET particle analyzer (Micromeritics) was used to determine the grain-size distribution of the samples. The samples were treated with $\mathrm{H}_{2} \mathrm{O}_{2}$ according to Jackson (1975) to remove organic matter and deflocculated in 0.5 $\%$ sodium pyrophosphate by stirring and ultrasonic treatment prior to analysis. Cumulative curves of the grain size distributions were recorded over the size range 60-2 $\mu \mathrm{m}$. Particles $>63 \mu \mathrm{m}$, if present, were separated from the samples by sieving before the sedimentation analysis. All results have been recalculated to bulk samples.

The ratio between the clay and the sand/coarse silt percentages gives some information on energy conditions during transport and sedimentation. A high ratio suggests calm conditions, low precipitation with little inwash from the catchment, i.e. conditions likely prevailing during arid, cold periods with short, ice-free summer seasons.

\section{Organic matter and carbonates}

The total carbon content was determined by stepped heating of the dried, homogenized sample in oxygen in a Leco multiphase carbon analyzer (Leco RC 412), which measures the $\mathrm{CO}_{2}$ and the $\mathrm{H}_{2} \mathrm{O}$ evolved by IR detection. Organic matter is the predominant source of carbon in the samples. However, stepped combustion of the samples up to $500{ }^{\circ} \mathrm{C}$ to reduce the organic carbon content, followed by recombustion, made it possible to detect that low amounts of $\mathrm{CO}_{2}$ evolved in the temperature range $600-850^{\circ} \mathrm{C}$. Combustion of acid treated samples confirmed that this carbon is derived from a carbonate phase.

Nitrogen was determined by the Kjeldahlmethod.

The content of organic matter is reported as weight $\% \mathrm{C}$ of the dry matter $\left(105^{\circ} \mathrm{C}\right)$. In addition, organic carbon has also been tentatively expressed in terms of its accumulation rate.

The accumulation of $\mathrm{C}$ may often be a good indicator of the organic production in the lake and, as such, more or less directly linked to climate. Warmer conditions with longer ice-free summers increase the photosynthesis and thus the lake productivity. On the other hand, where the surrounding soils are the main source for the sediments, it may also be a direct function of the input of allochtonous organic matter into the lake. This is very likely in a lake like 'Lake Åsa'.

The $\mathrm{C} / \mathrm{N}$ ratio of organic matter changes during decomposition due to the preferential destruction of proteins and amino acids (Berner, 1971). Sediments formed in lakes that are richly supplied with refractory, allochtonous organic compounds from the catchment tend to have higher $\mathrm{C} / \mathrm{N}$ ratios than sediments formed mainly from autochtonous organic matter (Hansen, 1959). For the autochtonous organic matter, the major change in composition occurs during the residence in oxygenated waters and surface sediments, whereas changes are much less after burial (Berner, 1971; Pennington, 1978). Hence, low $\mathrm{C} / \mathrm{N}$ ratios may indicate a predominantly autochtonous source of the organic matter and/or that 
decomposition took place under more or less reducing conditions, possibly connected with long periods of ice-cover.

\section{Chemical analyses}

An analytical procedure of stepwise extraction was used to facilitate a separation of the allogenic and authigenic fractions of the sediment, as defined by Engstrom \& Wright (1984). Samples were first treated with $\mathrm{H}_{2} \mathrm{O}_{2}$ to destroy organic matter, followed by extraction into $1 \mathrm{M}$ hydroxylamine hydrochloride in $25 \%$ acetic acid (Chester \& Hughes, 1967; Engstrom et al., 1985). Each of the extracts were analysed for a suite of nine major ( $\mathrm{Si}, \mathrm{Al}, \mathrm{Fe}, \mathrm{Ca}, \mathrm{Mg}, \mathrm{Na}, \mathrm{K}, \mathrm{Mn}, \mathrm{P}$ ) and three minor elements $(\mathrm{Zn}, \mathrm{Sr}, \mathrm{Cu})$ by plasma atomic emission spectrometry (ICP-AES ARL 3520).

'Amorphous' silica was extracted into $0.2 \mathrm{M}$ $\mathrm{NaOH}$ at $100{ }^{\circ} \mathrm{C}$ for exactly 20 minutes according to the procedure of Krausse et al. (1983), slightly modified. In addition to $\mathrm{Si}, \mathrm{Fe}, \mathrm{Al}$ and $\mathrm{P}$ were determined in the extract by plasma atomic emission spectrometry.

With regard to the chemical parameters analysed, there are good reasons to believe that (1) the amount of amorphous $\mathrm{Si}$ is directly related to input of tephra, (2) the $\mathrm{Fe} / \mathrm{Mn}$ and the $\mathrm{Mg} / \mathrm{Ca}$ ratios, determined in the $\mathrm{H}_{2} \mathrm{O}_{2}$-extract, are related to the composition of a carbonate phase. The former ratio is connected to the redoxconditions in the sediment whereas (3) the $\mathrm{Mg} / \mathrm{Ca}$ ratio of the carbonate, as well as the $\mathrm{Si} / \mathrm{Al}$ ratio of the acid-soluble matter, is a result of other diagenetic processes. The palaeoenvironmental implications of the chemical variables will be discussed in more detail below.

\section{Mineralogic analysis}

With chemical and other data on the sediment core available, four levels of the core were sampled for mineralogic analyses. The mineralogy of the $<2 \mu \mathrm{m}$ fraction of the samples was determined by X-ray diffraction analysis of 'oriented' mounts prepared according to the filter membrane peel-off technique (Drever, 1973). In addition, randomly oriented powders were X-ray scanned over the region $58-65^{\circ} 2 \Theta$, to differentiate between di- and trioctahedral sub-groups of clay minerals. Diffractograms were recorded on a Philips diffractometer using the $\mathrm{K} \alpha$-radiation of a fine-focus $\mathrm{Cu}$-tube with a divergence slit of $1^{\circ}$. The X-ray generator was operated at $40 \mathrm{kV} / 20$ $\mathrm{mA}$ and the scanning speed was $1^{\circ} 2 \Theta / \mathrm{min}$.

Samples were first scanned air-dried. X-ray scanning was repeated after exposure of the mounts to ethylene glycol (EG) vapours in order to identify expandable clay minerals, such as smectites. Additional criteria for this characterisation have been achieved by X-ray scanning of potassium-saturated and of glycerol treated, $\mathrm{Mg}$ saturated samples.

Two of the samples were also X-ray scanned before and after the extraction procedure to test the stability of the minerogenic matter towards the extractants used.

The mineralogic analyses were carried out to achieve a better understanding of the sediment chemistry.

\section{Pollen and spore analyses}

The pollen, spore and Pediastrum analyses were carried out on the $10 \mathrm{~cm}$ cores, and one additional surface sample. $1 \mathrm{~cm}^{3}$ samples were sampled and Lycopodium spores were added in order to estimate the concentration values. The sample preparations were in general the same as alternative $\mathrm{A}$ in Berglund \& Ralska-Jasiewiczowa (1987).

Very few pollen grains were found in the samples (between 0 and 9 grains), and of the two pollen producing plants in the area, only grains of grasses, probably of Deschampsia antarctica, were found, while Colobanthus quitensis grains are missing, although the plant is found within $500 \mathrm{~m}$ from 'Lake Åsa'. The other identified pollen types are Ulmaceae, Nothofagus and a group called 'Other pollen' which contains a few grains of Ephedera andiva, cf. Gentiana, Atriplex lampa 
(Chenopodiaceae), cf. Mulinum, and Betulacea. We generally consider all of these 'exotic' grains as transported from long distances (cf. Kappen \& Straka, 1988).

The amount of spores found varies between 24 and 1320. Most of the spores were difficult to identify. They have been photographed (Fig. 3), described and grouped as follows:

Moss spore A: Spheroidal spore, 22-32 $\mu \mathrm{m}$ in diameter. Inaperturate with microreticulate or granulate sculpturing.

Moss spore B: Spheroidal spore, 14-25 $\mu \mathrm{m}$ in diameter. Inaperturate with verrucate sculpturing. (Fig. 3D).

Lichen spore A(Usnea?): Spheroidal-oval spore, $10-30 \mu \mathrm{m}$ in diameter. Thin transparent wall without sculpturing. (Fig. 3E).

Lichen spore $B$ (Alectoria nigricans?): Elipsoidal spore, $20-30 \mu \mathrm{m} \times 10-15 \mu \mathrm{m}$ in size with one pore at both ends. The wall is thick, brown and smooth.

Type 1: Spheroidal spore, about $50 \mu \mathrm{m}$ in diameter. Inaperturate, thin wall with smooth surface and often folded. (Fig. 3F).

Type 2: A general group of trilete spores.

Type 3: Spheroidal spore, $10-15 \mu \mathrm{m}$ in diameter. Thick and inaperturate wall with elements on the surface. (Fig. 3G).

Type 4: Clusters of small spheroidal spores with thin walls. Fungal spores?

Type 5: Fungal spore?, quadroangular, c. 15 $\mu \mathrm{m} \times 15 \mu \mathrm{m}$ in size. Thinner walls at two opposite sides.

Type 6: Elipsoidal spore, c. $13 \mu \mathrm{m} \times 10 \mu \mathrm{m}$. Thick wall with very thin exine $(<1 \mu \mathrm{m})$ on the surface.

Type 7: Spheriodal spore, $10 \mu \mathrm{m}$ in diameter. The wall is thick and brown with four porelike openings. (Fig. $3 \mathrm{H}$ ).

Type 8: Hyalin spore with retuse angle and smooth surface.

Type 9: A small spheriodal spore, c. $6 \mu \mathrm{m}$ in diameter. Thin wall, slightly darker than type 6 . (Fig. 3I).

Type 10: Spheriodal spore(?), c. $23 \mu \mathrm{m}$ in diameter with a $5 \mu \mathrm{m}$ wide band around. A porelike opening in the center.
Type 11: Other spores.

The results from these analyses may be an important complement to reconstruct the development of the lake and its catchment. High influx values of lichen spores are interpreted as evidence of increased overland flow from the surroundings, probably caused by increased precipitation. Increased influx of long distance transported pollen grains was most likely caused by an increased influence of milder and more humid air-masses. Peaks in influx of Deschampsia antarctica grains may correspond to milder periods with more favorable growth conditions. High values of other spores (probably mainly from mosses, incl. aquatic mosses) possibly also indicate milder periods. Such mild conditions also imply increased precipitation, erosion, and inwash of grains from the catchment. High influx values of Pediastrum kawraisky colonies indicate good light conditions (less suspended matter in the water), good nutrient supply, 1-2 months of ice-free conditions, and relatively mild water temperatures during the growing season (Torbjörn Willén; pers. comm.).

\section{Diatom analyses}

The preparation of the samples, taken at $5-10 \mathrm{~cm}$ intervals, was carried out according to Håkansson (1984). Naphrax was used as the mounting medium. 350-600 diatoms were counted in each sample (with the exception of the $0.90 \mathrm{~m}$ sample, where the ash-layer was dominant and only a few diatoms were found). Some diatoms are only present as single or scattered occurrence (less than $1-2 \%$ ) in various levels of the core and are therefore not used in the main diagram. Only 31 taxa are chosen as representatives in the main diagram. A complete species list is given as an Appendix, where those taxa considered aerophilous, eu-terrestrial or bryophytic are given with an asterisk (Beger, 1927; Bock, 1963; Brendemühl, 1950; Foged, 1980; Hustedt, 1934, 1942; Krasske, 1932, 1938, 1939; Lund, 1945/46; Petersen, 1928, 1935; Round, 1957; Schwabe, 1970).

The $\mathrm{pH}$ grouping follows the system by $\mathrm{Hu}-$ stedt (1938-39). Information on the $\mathrm{pH}$ prefer- 

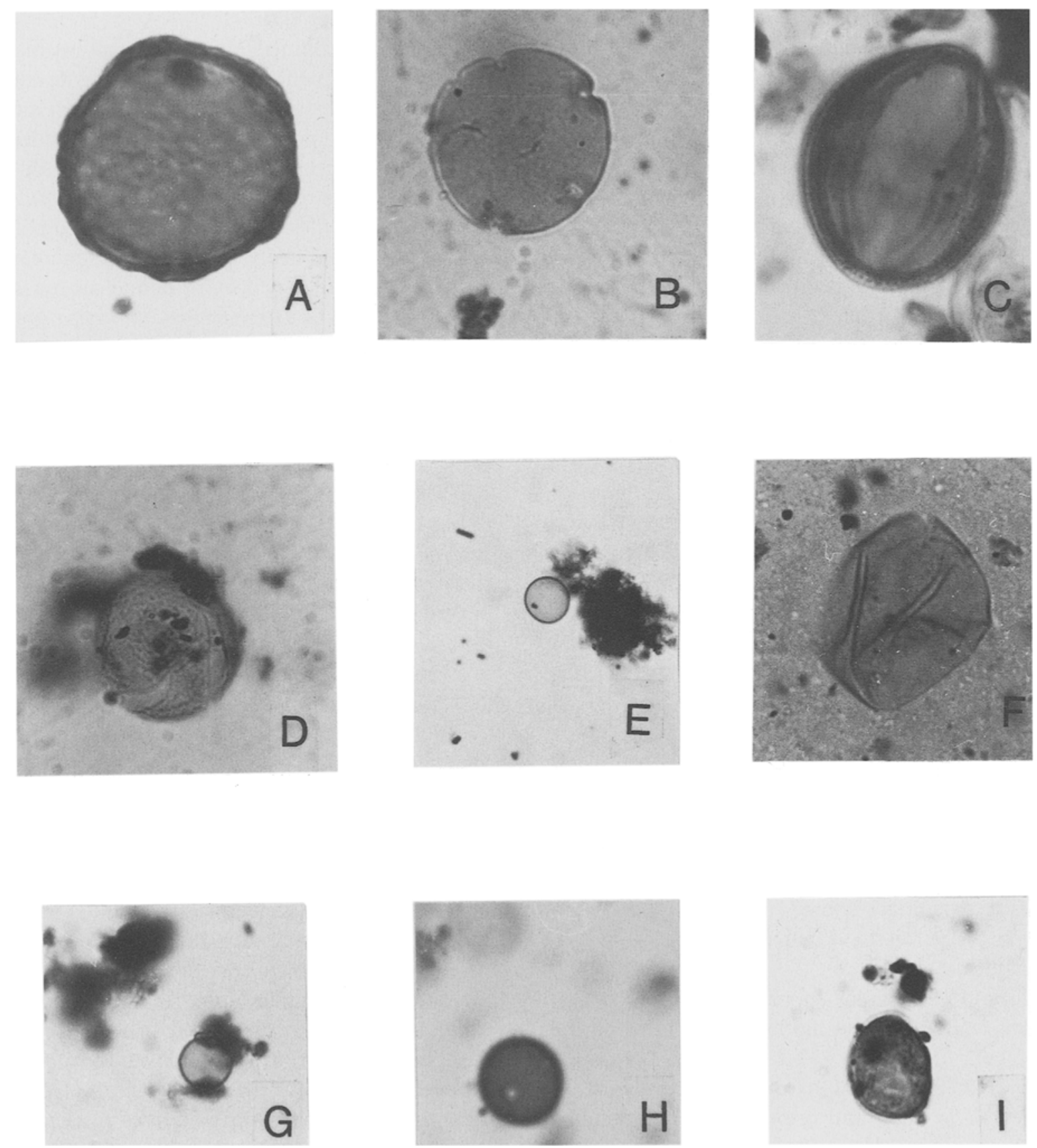

Fig. 3. Photographs of nine of the most common pollen grains and spores found in the sediments of 'Lake Åsa'. A-C are long distance transported pollen grains, D-I are spores described in the text. Values in brackets indicate size. A. Ulmaceae $(64 \mu \mathrm{m})$, B. Nothofagus $(20 \mu \mathrm{m})$, C. cf. Gentianaceae $(25 \mu \mathrm{m})$, D. Moss spore type B $(17 \mu \mathrm{m})$, E. Lichen spore type A (13 $\mu \mathrm{m})$, F. Type $1(100 \mu \mathrm{m}), \mathrm{G}$. Type $3(10 \mu \mathrm{m}), \mathrm{H}$. Type $7(10 \mu \mathrm{m})$, I. Type $9(6 \mu \mathrm{m})$.

ence of the different taxa was mostly obtained from papers by Cholnoky (1968), Cleve-Euler (1951-1955), Foged (1980, 1982), Hustedt
(1930-66), Patrick \& Reimer (1966, 1972) and Salden (1978).

Species identification is mainly based on liter- 
Table 1. Sediment lithology in the two main cores from 'Lake Åsa'. The ash-layers are numbered according to Björck et al. (1991c). LB = lower boundary, $\mathrm{G}=$ gradual, $\mathrm{RG}=$ rather gradual, $\mathrm{S}=$ sharp, $\mathrm{RS}=$ rather sharp, $\mathrm{D}=$ diffuse.

\begin{tabular}{|c|c|c|c|}
\hline \multirow{2}{*}{$\begin{array}{l}\text { Layer } \\
\text { no. }\end{array}$} & \multicolumn{2}{|c|}{ Depth below sed surface $(\mathrm{cm})$} & \multirow[t]{2}{*}{ Lithology } \\
\hline & $5 \mathrm{~cm}$ core & $10 \mathrm{~cm}$ core & \\
\hline 1 & $0.0-4.5$ & $0.0-12.0$ & $\begin{array}{l}\text { Clay gyttja, grey brown. Very loose in structure. This layer contains an } \\
\text { ash-layer (AP2), } 0.2-0.5 \mathrm{~cm} \text { thick, in its uppermost part. } \mathrm{LB}=\mathrm{RG}\end{array}$ \\
\hline 2 & $4.5-7.5$ & $12.0-15.0$ & Silty gyttja clay, grey. Faintly laminated by dark ash-layers. $L B=R G$ \\
\hline 3 & $7.5-8.5$ & $15.0-15.5$ & Silty volcanic ash (AP3), greyish-black. LB $=\mathrm{S}$ \\
\hline 4 & $8.5-9.0$ & $15.5-16.0$ & Silty gyttja clay, grey. LB = RS \\
\hline 5 & $9.0-9.5$ & $16.0-17.0$ & Sandy, silty volcanic ash (AP3), greyish-black. LB $=S$ \\
\hline 6 & $9.5-17.5$ & $17.0-23.5$ & Clay gyttja, grey. Some moss remains. $\mathrm{LB}=\mathrm{RS}$ \\
\hline 7 & $17.5-18.0$ & $23.5-24.0$ & $\begin{array}{l}\text { Silty volcanic ash (AP5), greyish-black. A relatively diffuse ash-layer. } \\
\mathrm{LB}=\mathrm{S}\end{array}$ \\
\hline 8 & $18.0-20.5$ & $24.0-27.5$ & Clay gyttja, bluish-grey. Some moss remains. $\mathrm{LB}=\mathrm{RS}$ \\
\hline 9 & $20.5-21.0$ & $27.5-27.7$ & Sandy, silty volcanic ash (AP5), greyish-black. $L B=S$ \\
\hline 10 & Missing? & $27.7-28.5$ & Clay gyttja, grey. Some moss remains. $\mathrm{LB}=\mathrm{RS}$ \\
\hline 11 & $20.5-21.0$ & $28.5-28.8$ & Sandy volcanic ash (AP5), greyish-black. $\mathrm{LB}=\mathrm{S}$ \\
\hline 12 & $21.0-22.5$ & $28.8-30.5$ & Clay gyttja, bluish-grey. Some moss remains. LB $=\mathrm{RS}$ \\
\hline 13 & $22.5-32.0$ & $30.5-41.0$ & Clay gyttja, grey. Some moss remains. $L B=G$ \\
\hline 14 & $32.0-33.0$ & $41.0-42.0$ & Clay gyttja, brownish-grey. Some moss remains. $\mathrm{LB}=\mathrm{G}$ \\
\hline 15 & $33.0-35.0$ & $42.0-44.5$ & Sandy, silty clay gyttja, grey. Some moss remains and gravel. $L B=R S$ \\
\hline 16 & $35.0-82.5$ & $44.5-82.5$ & $\begin{array}{l}\text { Laminated clay gyttja, light brown, brownish-grey, grey, greenish-grey } \\
\text { and always with a bluish tone. The laminae are } 1-5 \mathrm{~mm} \text { thick. Very few } \\
\text { moss remains. Brownish laminae at } 62.5-63 \mathrm{~cm} \text { and pebbles at } 52 \text { and } \\
67 \mathrm{~cm} \text {. LB = D }\end{array}$ \\
\hline 17 & $82.5-94.0$ & $82.5-89.0$ & $\begin{array}{l}\text { Laminated clay gyttja, darkish-grey. The laminae are made up as thin } \\
\text { black ash layers. Between } 82.5 \text { and } 87 \mathrm{~cm} 17 \text { laminae were counted. } \\
\mathrm{LB}=\mathrm{S}\end{array}$ \\
\hline 18 & $94.0-95.5$ & $89.0-91.0$ & Silty, sandy volcanic ash (AP10), greyish-black. $\mathrm{LB}=\mathrm{S}$ \\
\hline 19 & $95.5-100.0$ & $91.0-102.0$ & $\begin{array}{l}\text { Clay gyttja, brown to greenish-brown. The upper part faintly laminated, } \\
\text { and the lower part more darkish from the ash. LB = RS }\end{array}$ \\
\hline 20 & Missing? & $102.0-102.3$ & Silty volcanic ash (AP11), greyish-black. $\mathrm{LB}=\mathrm{S}$ \\
\hline 21 & $100.0-104.0$ & $102.3-109.0$ & Laminated clay gyttja, light brown to grey. Some moss remains. $L B=G$ \\
\hline 22 & $104.0-112.0$ & $109.0-118.5$ & $\begin{array}{l}\text { Laminated clay gyttja, darkish-grey to brown, occasionally bluish. The } \\
\text { lower part gradually darker. } \mathrm{LB}=\mathrm{G}\end{array}$ \\
\hline 23 & $112.0-114.5$ & $118.5-121.0$ & Sandy, silty volcanic ash (AP12), greyish-black. LB $=\mathrm{S}$ \\
\hline 24 & $114.5-126$ & $121.0-135.0$ & $\begin{array}{l}\text { Laminated clay gyttja, light brown, dark grey, and occasionally bluish. } \\
\text { Some moss remains. LB }=\mathrm{G}\end{array}$ \\
\hline 25 & $126.0-190.0$ & $135.0-203.0$ & $\begin{array}{l}\text { Laminated clay gyttja, brown to grey brown. Some moss remains but at } \\
\text { three levels }(164-167,173-174 \text {, and } 199-200 \mathrm{~cm}) \text { very rich in mosses. } \\
\text { LB }=\text { RG }\end{array}$ \\
\hline 26 & $190.0-200.0$ & $203.0-210.0$ & Gyttja clay, dark brown. Very rich in mosses. $\mathrm{LB}=\mathrm{RS}$ \\
\hline 27 & $200.0-204.5$ & $210.0-213.5$ & $\begin{array}{l}\text { Silty gyttja clay, blackish-grey. Rather rich in moss-remains. Thin lam- } \\
\text { ina of a mixture of gravel and ash. } \mathrm{LB}=\mathrm{G}\end{array}$ \\
\hline 28 & $204.5-205.5$ & $213.5-217.5$ & $\begin{array}{l}\text { Mixture of volcanic ash (AP14) and clayey, slightly organic sediments, } \\
\text { greyish-black. Some moss remains. LB }=\mathrm{S}\end{array}$ \\
\hline 29 & Missing & $217.5-218.5$ & Silt, grey. \\
\hline
\end{tabular}

ature from the Subantarctic and Arctic: Cleve (1894-95), Carlsson (1913), Bourelley \& Manguin (1954), Le Cohu \& Maillard (1983, 1986), Lange-Bertalot \& Schmidt in Schmidt et al.
(1990), Van Heurck (1908), but also from Krammer \& Lange-Bertalot (1986, 1988, 1991a, b), and Round et al. (1990). 


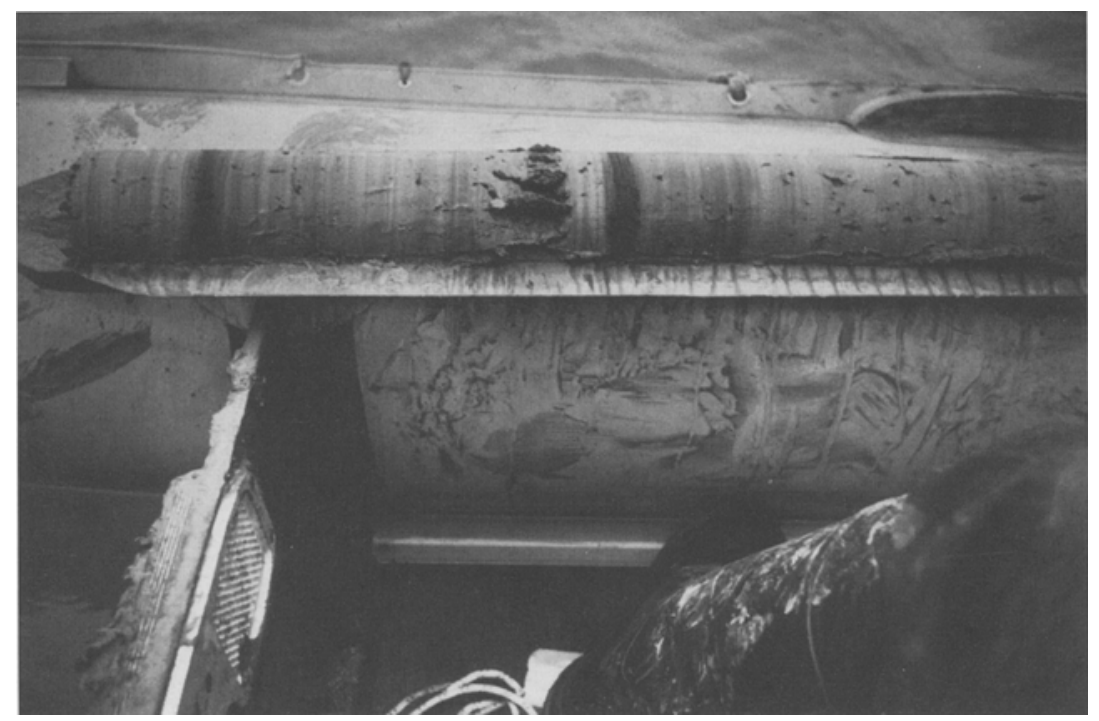

Fig. 4. Photograph of one of the $10 \mathrm{~cm}$ cores showing two of the thick tephra horizons, AP12 (left) and AP10 (right), while the thin AP11 is hard to distinguish. Bottom of the core is to the left; notice the sharp lower boundary and the influence of tephra above the actual tephra horizon.

\section{Moss analyses}

25 levels with visible occurrences of mosses were sampled for moss analyses. The moss fragments were wet screened from the mineral sediment with tap water, and a mild wetting agent added (Aerosol OT, Fisher). The fragments remaining on a screen were extracted and stored in glycerol. The best preserved fragments were mounted in Hoy-

Table 2. Tephra horizons found in 'Lake Åsa' (Table 1), related to age and the regional tephrochronology.

\begin{tabular}{lccl}
\hline $\begin{array}{l}\text { Depth }(\mathrm{cm}) \\
10 \mathrm{~cm} \text { core }\end{array}$ & $\begin{array}{l}\text { Depth }(\mathrm{cm}) \\
5 \mathrm{~cm} \text { core }\end{array}$ & $\begin{array}{l}\text { Calculated age } \\
\left({ }^{14} \mathrm{C} \text { yr BP }\right)\end{array}$ & $\begin{array}{l}\text { Tephra horizon } \\
\text { acc. to } \\
\text { Björck } \text { et al. } \\
(1991 \mathrm{c})\end{array}$ \\
\hline $5.5-6.0$ & $0.5-0.7$ & 450 & AP2 \\
$15.0-15.5$ & $7.5-8.5$ & $750-800$ & AP3 \\
$16.0-17.0$ & $9.0-9.5$ & $750-800$ & AP3 \\
$23.5-24.0$ & $17.5-18.0$ & $1250-1400$ & AP5 \\
$27.5-27.7$ & $20.5-21.0$ & $1250-1400$ & AP5 \\
$28.5-28.8$ & $20.5-21.0$ & $1250-1400$ & AP5 \\
$89.0-91.0$ & $94.0-95.5$ & 2630 & AP10 \\
$102.0-102.3$ & Missing? & 2710 & AP11 \\
$118.5-121.0$ & $112.0-114.5$ & 2760 & AP12 \\
$213.5-217.5$ & $204.5-205.5$ & 4750 & AP14 \\
\hline
\end{tabular}

er's (Schuster 1966) and studied with a compound microscope.

Identification was accomplished by critical comparison with voucher collections of Antarctic specimens. After the species composition of the assemblages was determined, abundance counts of the less-well preserved fragments were made and the reliability of the taxa assessed (see Table 4 and Janssens, 1990).

Periods with sediments barren in mosses may indicate harsh growing conditions for the mosses on the bottom of the lake, like e.g. bottomfreezing. Periods with high input of terrestrial mosses suggest high erosion and inwash from the catchment, which is an indication of higher precipitation.

\section{Results \\ General lithology, chronology and sediment accu- mulation}

The lithology of the 'Lake Åsa' sediments is described in Table 1. Without the tephra layers (Fig. 4), the lithologic changes would have been rather subtle, but due to the diverging color and 
particle size of the tephras the volcanic ash material partly characterizes the sediments deposited even some time after the tephra fall-outs. Typically the lower boundary of a tephra is very distinct, while the upper boundary is gradual. In spite of the presence of mosses, the sediments are poor in organic matter. In fact the loss-on-ignition analyses give 3-4 times higher values than the organic carbon analyses, which indicates a high content of crystal water in the minerogenic matter.

Altogether $14{ }^{14} \mathrm{C}$ analyses were performed on 11 levels (Table 2). On two of the levels it was possible to pick out mosses to date both the pure mosses and the moss-free sediment and in one sample both the $\mathrm{NaOH}$-soluble and insoluble fractions were dated. As Björck et al. (1991d) point out, there are major dating problems in the Antarctic environment and of the 14 dates from 'Lake Åsa' only three are regarded as reliable, Lu-3088, Lu-3089, and Lu-3134A, of which two are pure moss dates. This is supported by crosscorrelations to the tephrochronology (Björck et al. 1991b), which is based on pure moss dates (Table 3). Possible reasons for the many and large errors of the 'Lake Assa' dates are discussed by Björck et al. (1991d).

Based on the three reliable dates and the dated tephra layers (mainly from the moss bank on Elephant Island and the AMS dates from Midge
Lake), it was possible to construct a rather detailed age/depth curve for the 'Lake Åsa' sediments (Fig. 5). Because of the silt and tephra material in the very bottom (layers 29-28), the accumulation is assumed to have been rather rapid (1-2 mm/yr). Between 4700 and $4000 \mathrm{BP}$ the rate gradually decreased to $c a .0 .3 \mathrm{~mm} / \mathrm{yr}$. This trend seems to have changed and a gradually increasing sedimentation rate (from 0.3 to 0.9 $\mathrm{mm} / \mathrm{yr}$ ) is postulated for the period $4000-2800$ BP (Fig. 5). During, between, and slightly after the deposition of tephra layers AP12-AP10 (layers 23-17), the sedimentation varied between $1.5-3 \mathrm{~mm} / \mathrm{yr}$. The mean rate of this period is more or less identical to the rate in layer $16(\mathrm{Ta}-$ ble 1) if the 17 laminae between 82.5 and $87 \mathrm{~cm}$ are annual. After 2600 the rate once again gradually slowed down from 1.2 to $0.2 \mathrm{~mm} / \mathrm{yr}$ between 2500-1400 BP. Further tephra horizons (AP5, $\mathrm{AP} 3$, and AP2) increased the accumulation rate again $(0.3-0.4 \mathrm{~mm} / \mathrm{yr})$ after $1400 \mathrm{BP}$, but based on the ages of these tephras (Table 3 ) the rates never came close to the rates between 2800 and 2600 BP. The extremely rapid sedimentation around $2700 \mathrm{BP}$ can partly be explained by the occurrence of tephras, but tephra deposition is probably not the only cause of the large scale changes seen in Fig. 5. These accumulation rate changes are very similar, both with respect to

Table 3. Radiocarbon dates from the $10 \mathrm{~cm}$ core in 'Lake Åsa'

\begin{tabular}{|c|c|c|c|c|}
\hline $\begin{array}{l}\text { Depth below } \\
\text { sed. surface }(\mathrm{cm})\end{array}$ & Dated material & $\begin{array}{l}{ }^{14} \mathrm{C} \text { age } \\
\text { yrs BP }\end{array}$ & $\begin{array}{l}\delta^{13} \mathrm{C} \\
(\%)\end{array}$ & Lab. no. \\
\hline $4-7$ & Bulk sediment & $1140 \pm 160$ & -17.3 & Lu-3135 \\
\hline $17-22$ & Bulk sediment & $2840 \pm 80$ & -19.1 & Lu-3090 \\
\hline $29-34$ & Bulk sediment & $2850 \pm 80$ & -18.7 & Lu-3128 \\
\hline $40-50$ & Insoluble fraction & $7850 \pm 150$ & -23.3 & Lu-3134 \\
\hline $40-50$ & Soluble fraction & $2240 \pm 80$ & -18.7 & Lu-3134a \\
\hline $60-65$ & Bulk sediment & $3110 \pm 60$ & -17.4 & Lu-3129 \\
\hline $83.5-88.5$ & Bulk sediment & $3570 \pm 100$ & -17.0 & Lu-3130 \\
\hline $91-96$ & Bulk sediment & $3170 \pm 70$ & -17.0 & Lu-3131 \\
\hline $112-117$ & Bulk sediment & $3920 \pm 90$ & -18.0 & Lu-3132 \\
\hline $121-126$ & Bulk sediment & $3930 \pm 80$ & -17.4 & Lu-3133 \\
\hline $163-168$ & Aquatic mosses & $3480 \pm 140$ & -25.2 & Lu-3089 \\
\hline $163-168$ & Soluble fraction & $5240 \pm 890$ & -23.7 & Lu-3089a \\
\hline $205-210$ & Aquatic mosses & $4600 \pm 100$ & -27.8 & Lu-3088 \\
\hline $205-210$ & Bulk sediment & $5740 \pm 180$ & -24.6 & Lu-3088a \\
\hline
\end{tabular}




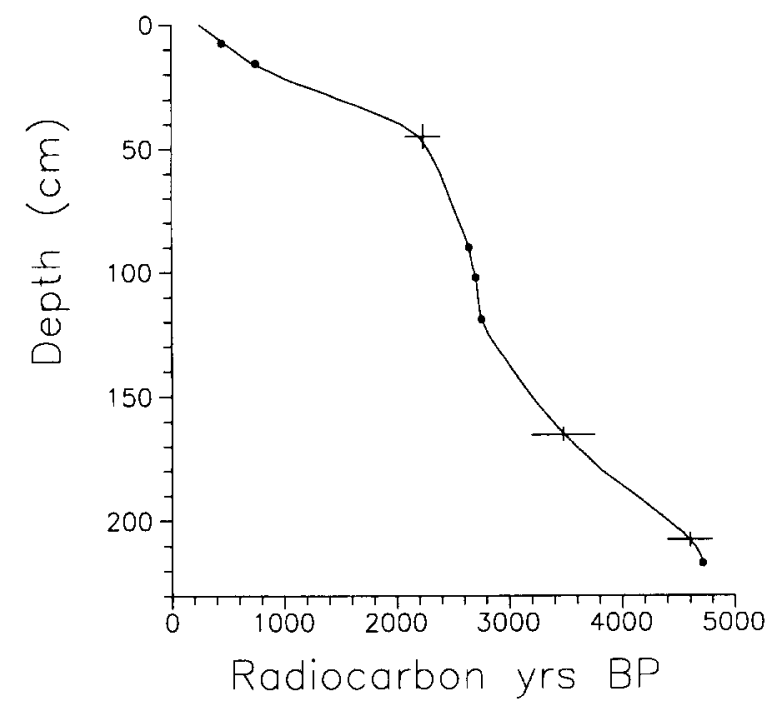

Fig. 5. Age/depth curve for the $10 \mathrm{~cm}$ core in 'Lake Åsa'. The curve is based on three of the ${ }^{14} \mathrm{C}$ dates in Table 3 and the cross-correlated and moss dated tephra horizons, indicated by dots.

timing and magnitude, to those found in Midge Lake (Björck et al. 1991 a) and in the moss bank on Elephant Island (Björck et al. 1991c).
A very distinct ${ }^{137} \mathrm{Cs}$ peak occurs $2.4-3.6 \mathrm{~cm}$ from the top (Roos et al., 1992) and together with the ${ }^{210} \mathrm{~Pb}$ values, an accumulation rate of $0.3-0.6$ $\mathrm{mm} / \mathrm{yr}$ for the uppermost $5-6 \mathrm{~cm}$ is calculated (Roos et al., 1992). They also found that the ${ }^{137} \mathrm{Cs}$ peak coincides with a peak of ${ }^{238} \mathrm{Pu}$. About $90 \%$ of the total ${ }^{238} \mathrm{Pu}$ fall-out originate from the reentry burnup of the SNAP-9A generator in 1964. Although some sediment mixing may occur in winter if the lake bottom-freezes, there thus seems to be a more or less continuous recent sedimentation. Based on the radionuclide analyses we have estimated that $c a .10 \mathrm{~cm}$ ( $c a .300$ years) of the uppermost stratigraphy is missing in the 10 $\mathrm{cm}$ core.

The particle size analyses (Fig. 6) show that the clay content varies between 8 and $63 \%$, while the content of sand varies between 0 and $18 \%$. Some of the coarsest samples come from the ash layers, but apart from those there are some general trends in the particle size. From the onset of sedimentation until slightly before $2700 \mathrm{BP}$, there are significant particle size variations, with deposition of coarse sediments occurring mainly between 4700

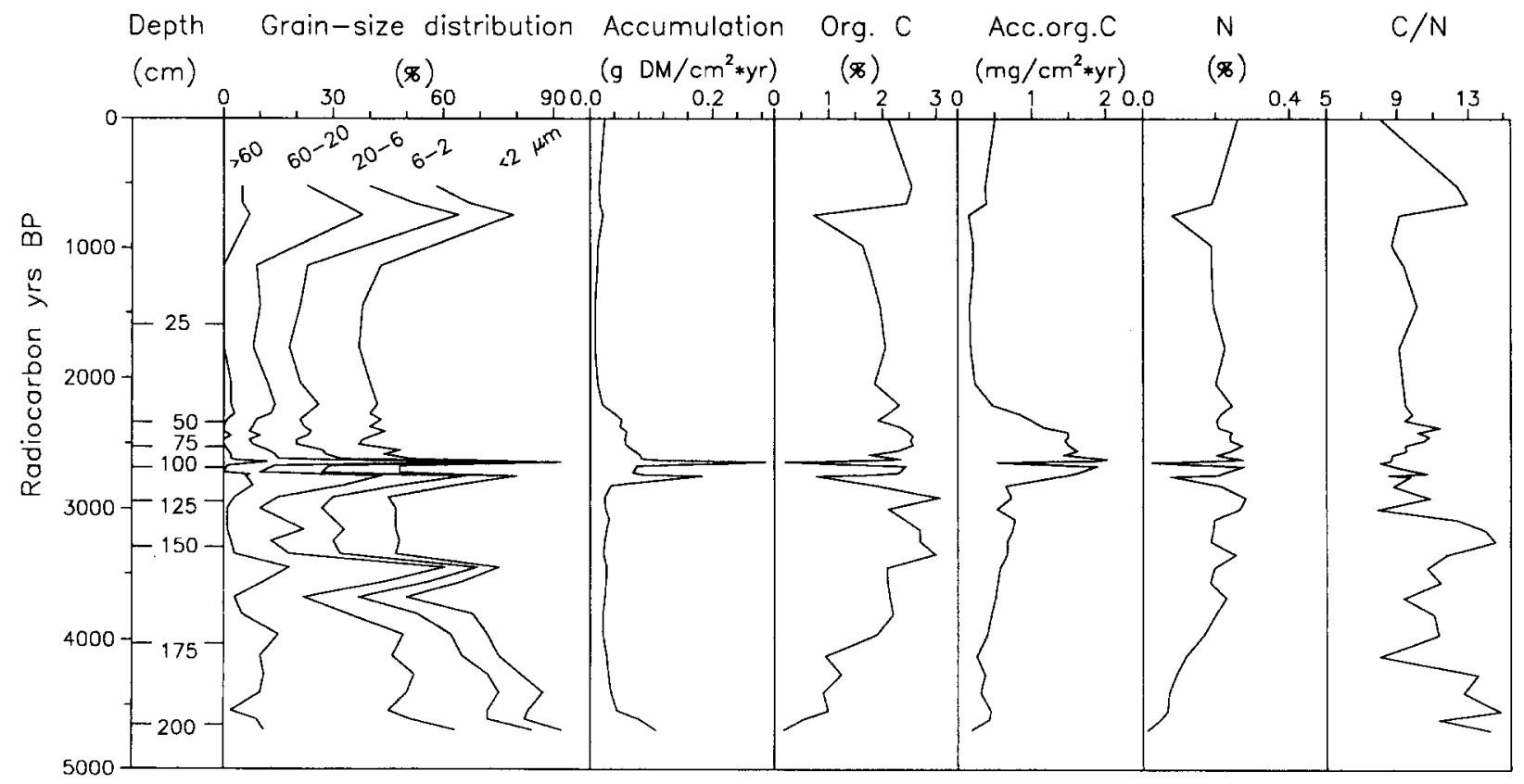

Fig. 6. Summary of the results of grain-size, accumulation rates, organic carbon and nitrogen determinations. DM $=$ dry matter. 
Table 4. Moss stratigraphy in the $10 \mathrm{~cm}$ core from 'Lake Åsa'. The sediments between 41 and $102 \mathrm{~cm}$ are more or less barren in mosses (Table 1). $\mathrm{A}=$ Abundance, $\mathrm{R}=$ Reliability (an index of preservation degree, from 0-10, after Janssens, 1990)

\begin{tabular}{|c|c|c|c|c|}
\hline Depth $(\mathrm{cm})$ & ${ }^{14} \mathrm{C}$ yrs BP & Identified brypohyte taxons & A & $\mathrm{R}$ \\
\hline 32.5 & 1650 & Warnstorfia cf. exannulata (B.S.G.) Loeske & 1 & 7 \\
\hline 102.5 & 2710 & Bryopsida & 2 & 2 \\
\hline \multirow[t]{3}{*}{105.0} & 2720 & Bryum $\mathrm{cf}$. dichotomum Hedw. & 1 & 6 \\
\hline & & Bryum sp. & 2 & 2 \\
\hline & & Drepanocladus sp. & 4 & 2 \\
\hline 107.5 & 2730 & Bryopsida & 1 & 2 \\
\hline \multirow[t]{3}{*}{130.0} & 2890 & Sarmentypum sarmentosum (Wahlenb.) Tuom. et Kop. & 9 & 7 \\
\hline & & Drepanocladus sp. & 2 & 6 \\
\hline & & Bryopsida & 1 & 1 \\
\hline \multirow[t]{2}{*}{135.0} & 2970 & Sarmentypum sarmentosum (Wahlenb.) Tuom. et Kop. & 2 & 2 \\
\hline & & Bryopsida & 4 & 2 \\
\hline \multirow[t]{2}{*}{140.0} & 3040 & cf. Dicranoweisia antarctica (Muell.) Kindb. & 1 & 6 \\
\hline & & Warnstorfia exannulata (B.S.G.) Loeske & 3 & 9 \\
\hline \multirow[t]{3}{*}{145.0} & 3120 & cf. Brachytecium sp. & 1 & 3 \\
\hline & & Sarmentypum sarmentosum (Wahlenb.) Tuom. et Kop. & 1 & 7 \\
\hline & & cf. Warnstorfia exannulata (B.S.G.) Loeske & 1 & 3 \\
\hline 147.5 & 3160 & Sarmentypum sarmentosum (Wahlenb.) Tuom. et Kop. & 2 & 7 \\
\hline \multirow[t]{2}{*}{150.0} & 3200 & cf. Bryum sp. & 1 & 2 \\
\hline & & Warnstorfia exannulata (B.S.G.) Loeske & 5 & 8 \\
\hline 155.0 & 3290 & Warnstorfia exannulata (B.S.G.) Loeske & 1 & 7 \\
\hline \multirow[t]{3}{*}{160.0} & 3380 & cf. Bryum sp. & 1 & 2 \\
\hline & & Warnstorfia cf. exannulata (B.S.G.) Loeske & 1 & 6 \\
\hline & & cf. Drepanocladus sp. & 3 & 2 \\
\hline \multirow[t]{3}{*}{162.5} & 3430 & Sarmentypum cf, sarmentosum (Wahlenb.) Tuom. et Kop. & 1 & 7 \\
\hline & & Warnstorfia exannulata (B.S.G.) Loeske & 1 & 6 \\
\hline & & Drepanocladus sp. & 4 & 7 \\
\hline 167.5 & 3540 & Warnstorfia exannulata (B.S.G.) Loeske & 3 & 7 \\
\hline 170.0 & 3590 & Warnstorfia exannulata (B.S.G.) Loeske & 5 & 7 \\
\hline 172.5 & 3650 & Warnstorfia exannulata (B.S.G.) Loeske & 3 & 7 \\
\hline \multirow[t]{2}{*}{175.0} & 3710 & cf. Sarmentypum sarmentosum (Wahlenb.) Tuom. et Kop & 2 & 6 \\
\hline & & Warnstorfia exannulata (B.S.G.) Loeske & 2 & 7 \\
\hline 177.5 & 3770 & Drepanocladus sp. & 2 & 7 \\
\hline 180.0 & 3820 & Drepanocladus sp. & 2 & 7 \\
\hline \multirow[t]{4}{*}{187.5} & 4050 & cf. Bryum sp. & 1 & 4 \\
\hline & & Sarmentypum cf. sarmentosum (Wahlenb.) Tuom. et Kop. & 4 & 7 \\
\hline & & Warnstorfia exannulata (B.S.G.) Loeske & 2 & 7 \\
\hline & & cf. Polytrichales & 1 & 1 \\
\hline 190.0 & 4120 & Warnstorfia cf. exannulata (B.S.G.) Loeske & 1 & 7 \\
\hline 197.5 & 4330 & Warnstorfia exannulatus (B.S.G.) Loeske & 1 & 6 \\
\hline 200.0 & 4400 & Warnstorfia exannulatus (B.S.G.) Loeske & 4 & 8 \\
\hline 205.0 & 4540 & Warnstorfia exannulatus (B.S.G.) Loeske & 3 & 7 \\
\hline 207.5 & 4600 & Warnstorfia exannulatus (B.S.G.) Loeske & 4 & 7 \\
\hline
\end{tabular}

and $3900 \mathrm{BP}$ and $3600-3300 \mathrm{BP}$. In spite of the filling-in and thus shallowing of the lake the sediments become finer and homogenous after $c a$. 2700 BP. The only exceptions are ash layers or sediments deposited slightly after the ash fallouts.

\section{Organic matter}

From very low values $(<0.5 \% \mathrm{C})$ in the bottom samples, where moss-fragments make up a significant part of the organic matter, the organic content increases stepwise up to c. $4100 \mathrm{BP}$ 
(Fig. 6). The $\mathrm{C} / \mathrm{N}$ ratio of the organic matter is high in this lowermost interval of the sequence. Immediately after deglaciation, the erosional input from the catchment may have been a more important source of the organic matter than production in the lake, thus explaining the mature character of the organic matter in the bottom sediment.

Accompanying the upward fining trend, the organic content rises markedly between 4100 and 3800 BP. Macroscopic remains of mosses still occur, but moss-fragments are no longer the main source of the organic matter in the sediment, which gradually alters into gyttja clay and clay gyttja. A lowering of the $\mathrm{C} / \mathrm{N}$ ratio in this interval (Fig. 6) may reflect improved conditions for aquatic productivity and/or a lowered input by erosion, leading to changed proportions of the allochtonous/autochtonous components. It is also possible that decomposition was slowed down due to oxygen deficiency, which favored survival of juvenile and therefore highly reactive organic compounds in the sediment.

Most of the interval 3500-2800 BP consists of very fine-grained clay gyttja. The organic content reaches its maximum levels, c. $3 \%$, and the organic matter is characterized by high $\mathrm{C} / \mathrm{N}$ values (Fig. 6). Open water conditions would allow both improved replenishment of oxygen in the surface sediment and a high input of allochtonous matter. However, the fact that the accumulation of minerogenic matter remains relatively low suggests that the latter factor may have been less important than the former.

The return of the $\mathrm{C} / \mathrm{N}$ ratio to low values at $c a$. 3000 BP coincides with a drastic increase in sediment accumulation, which led to rapid burial of the organic matter. Apart for minor fluctuations, the ratio remains low in the sediment formed during and shortly after the period of ash fall-outs, i.e. to ca.. $2500 \mathrm{BP}$, when the sediment accumulation rate was at a maximum. The tephra-layers, which probably accumulated at very high rates, are distinguished by very low organic content (Fig. 6), whereas the organic content for the rest, in spite of the ash influence, remains surprisingly high, $2-2.5 \% \mathrm{C}$.
The time-span ca. 2500-800 BP is characterized by low and uniform accumulation of very fine-grained matter, indicating a low erosional input to the lake. The organic content is still fairly high, c. $2 \%$, but the calculated input of organic matter is at a minimum during this period. The $\mathrm{C} / \mathrm{N}$ ratio of the organic matter is low and relatively constant.

During the last 800 years, the accumulation of both organic and minerogenic matter appears to have increased slightly, but calculations of accumulation rates are probably uncertain for the uppermost, less compacted sediment. A higher erosional in put for the period following the deposition of the 720 BP tephra layer is indicated by a coarsening of the sediment grain-size, and is compatible also with the abrupt rise of the $\mathrm{C} / \mathrm{N}$ ratio after this event.

\section{Mineralogy}

The interval $205-185 \mathrm{~cm}$ at the base of the sediment sequence, corresponding to the time-span c. 4700-4200 BP, consists of a black sandy, clayey silt. The black colour of the sediment is due to a high, though upwards diminishing, mixture of, apparently redeposited, volcanic ash. Examination under a polarizing microscope of silt from this sediment showed that the majority of the grains consists of glass in various stages of alteration: from fairly angular grains of fresh, greenish-brown glass with few vesicles and with microlites of plagioclase over brownish, non-transparent, fairly rounded grains, with optically active or cryptocrystalline domains surrounding a nucleus of unaltered glass to completely altered, cryptocrystalline grains. The different appearance of the grains might indicate that the tephra consists of more than one tephra generation.

The mineralogic composition of the $<2 \mu \mathrm{m}$ fraction of this sediment is illustrated by the diffractograms in Fig. 7A. Smectite and chlorite are the predominating phyllosilicates with quartz and feldspar being the main non-clay minerals. A medium strong (060)-reflection at c. 1.54 A suggests that part of the smectite is of a trioctahedral type. Moreover, it is noteable that EG-solvation of the K-saturated clay fails to expand the phase, a be- 

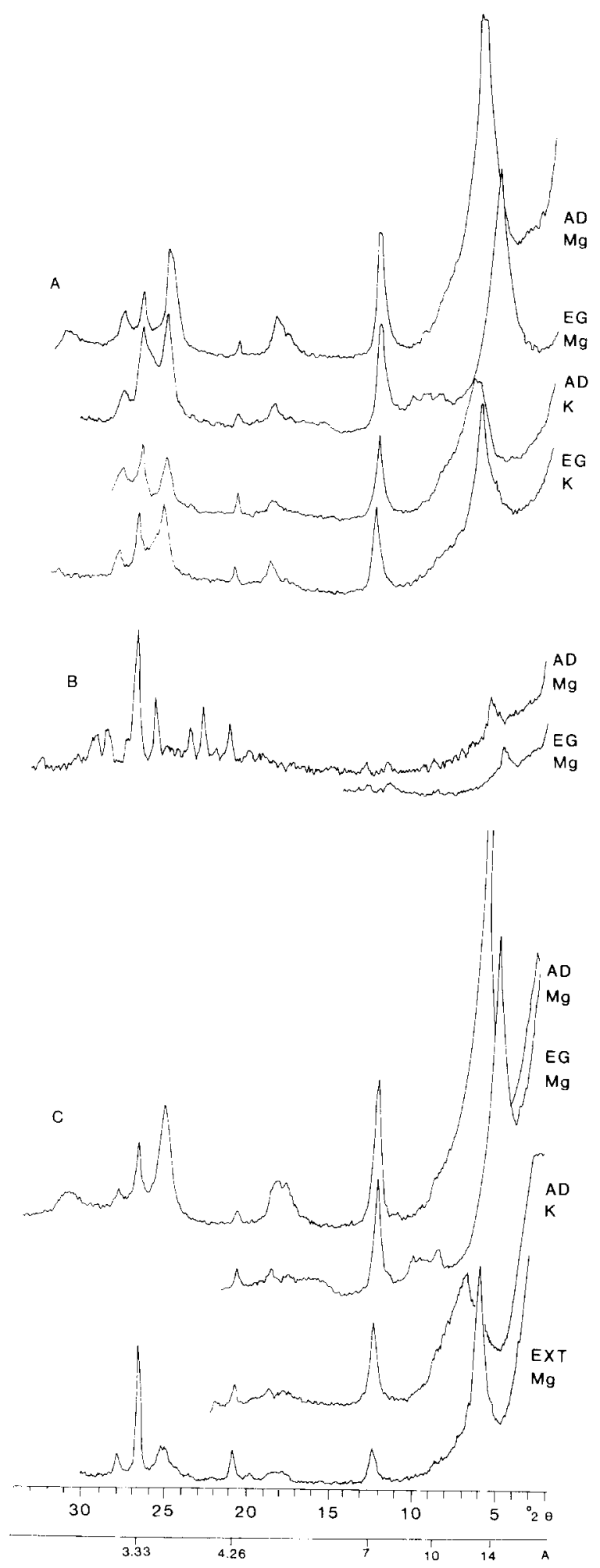

Fig. 7. X-ray diffractograms of the clay fraction of the sediment at A. $200 \mathrm{~cm}$ (ash-mixed sediment), B. $95 \mathrm{~cm}$ (pure te- haviour indicative of high-charge smectites and of vermiculites (McEwan \& Wilson 1980). It is wellknown that $\mathrm{Mg}$-rich, trioctahedral smectites often form from basaltic material under low temperature conditions (reviewed in Weaver 1989; April \& Keller 1992). According to Troian et al. (1990) both trioctahedral (saponite) and dioctahedral smectites (montmorillonite) occur in the pyroclastics on the South Shetland Islands and both smectite varieties have also been found in soils on the islands (Blümel et al., 1985).

In addition to the crystalline phases, the clay fraction of the 'ash-mixture' also contains some $\mathrm{X}$-ray amorphous material, as indicated by the slightly raised background of the diffractograms.

Most of the interval 165-115 cm, corresponding to the time-span c. 3600-2800 BP, consists of very fine-grained (more than $50 \%$ particles $<2$ $\mu \mathrm{m})$, brownish grey gyttja clay/clay gyttja. Diffractograms of the clay fraction of this sediment $(160 \mathrm{~cm})$ are very similar to those of Fig. 7A. Smectites, probably both di- and trioctahedral, and chlorite are the predominating phyllosilicates with minor amounts of quartz and feldspar being the main non-clay minerals.

During the time-span $2800 \mathrm{BP}-2600 \mathrm{BP}$, which coincides with a period of volcanic activity on Deception Island (Björck et al., 1991b), the sedimentation is again strongly influenced by a high input of volcanic ash. Apart from the pure tephralayers, dated to 2760,2710 and $2630 \mathrm{BP}$ (cf. Table 2), most of the interval $115-80 \mathrm{~cm}$ consists of clay gyttja, which is either black-coloured by mixed ash or finely laminated with thin ashdominated laminae.

As illustrated by the diffractograms in Fig. 7B $(95 \mathrm{~cm})$, the tephra-rich horizons are entirely different from the 'normal' sediment in mineralogic composition. The raised background of the diffractogram indicates that the ash has a high proportion of X-ray amorphous material and its clay-

phra), and C. $50 \mathrm{~cm}$ depth (see Table 1). AD = air-dried, $\mathrm{EG}=$ ethylene glycol solvated, $\mathrm{Mg}=\mathrm{Mg}$-saturated, $\mathrm{K}=\mathrm{K}$ saturated sample. EXT = sample after extraction with $\mathrm{H}_{2} \mathrm{O}_{2}$ and acid hydroxylamine hydrochloride solution. $\mathrm{CuK}_{x^{-}}$ radiation. 
mineral content is low. Interstratified minerals with a high proportion of smectitic layers are the main clay mineral and calcic plagioclase is the most abundant non-phyllosilicate. Also magnetite has been detected, thus supporting the magnetic measurements (Björck et al., 1991b), which show that ferri-magnetic minerals occur in the ash.

The interval $75-20 \mathrm{~cm}$ is characterized by very fine-grained sediments, with clay-contents typically exceeding $60 \%$. Diffractograms of a sample from this interval $(50 \mathrm{~cm}, \mathrm{Fig} .7 \mathrm{C})$ is dominated by a very strong $14 \mathrm{~A}$ peak. An increase of the intensity ratio of the 14 (smectite + chlorite) and 7 A peaks (chlorite) by more than $50 \%$ indicates that the proportion of smectite relative to chlorite is considerably higher than in previous samples.

Examination (XRD) of the samples collected in the catchment reveal that the source material of the soils originate not only from the local sandstones, shales and basalts, but also to a large extent from the wind transported tephra material. It is noteable, however, that the clay mineral suite of the ash-mixed soil sample analysed is dominated by smectite, whereas chlorite is absent.

\section{Geochemistry}

The total amount of extractable $\mathrm{Na}$ and $\mathrm{K}$ is low ( Na $<50 \mu \mathrm{g} / \mathrm{g} \mathrm{DM} ; \mathrm{K}<150 \mu \mathrm{g} / \mathrm{g}$ DM) and fairly constant. A major portion of the total extractable amounts of these cations is released during the first step of the extraction procedure, i.e. during treatment with $\mathrm{H}_{2} \mathrm{O}_{2}$-solution (c. $70 \%$ of $\mathrm{Na}$; c. $65 \%$ of $\mathrm{K}$ ). It is probable that $\mathrm{Na}$ and $\mathrm{K}$ in this solution are derived mainly from the population of loosely sorbed and dissolved ions in the pore water. Fig. 8 shows the stratigraphic distribution of $\mathrm{Na}$ and $\mathrm{K}$, with concentrations expressed in $\mu \mathrm{mol} / \mathrm{g}$ water (calculated from water contents). Concentration maxima for both ions around ashlayers and in the ash-rich bottom sediment show that the tephra material, which has a high content of glass, supports higher $\mathrm{Na}$ - and $\mathrm{K}$ levels in the pore water than the rest of the sediment. Ashlayers are distinguished also by their higher proportion of $\mathrm{Na}$, as illustrated by the $\mathrm{Na} / \mathrm{K}$ ratio in Fig. 8.

The carbon analysis shows that a carbonate phase occurs throughout the entire sequence of sediment, though in very low amounts, generally corresponding to $<0.15 \% \mathrm{C}$. Hence, the car-

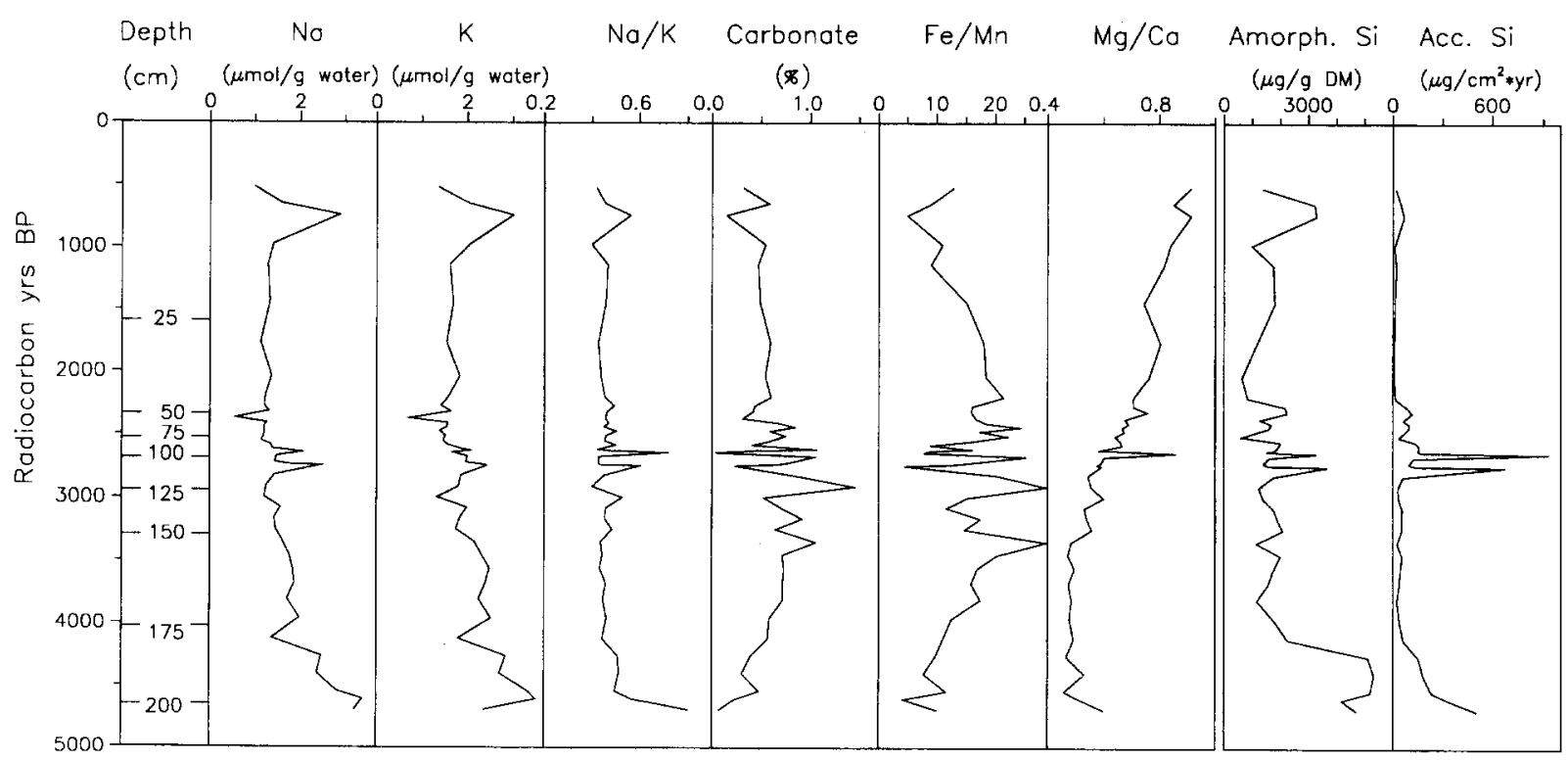

Fig. 8. The stratigraphic distribution of $\mathrm{H}_{2} \mathrm{O}_{2}$-extractable $\mathrm{Na}$ and $\mathrm{K}$, carbonate and the $\mathrm{Fe} / \mathrm{Mn}$ and $\mathrm{Mg} / \mathrm{Ca}$ ratio of the carbonate phase. The right hand diagram shows the stratigraphic distribution of alkali-soluble silica, expressed in concentration units and in terms of its accumulation rate. 
bonate could be detected by XRD-analysis only in a fraction of the sediment, which had been enriched in heavy minerals. Solid solution is common in carbonates, most frequent being those which involve replacement of $\mathrm{Ca}$ by $\mathrm{Mg}$ and/or $\mathrm{Mn}$. $\mathrm{Mn}$ and $\mathrm{Mg}$ can replace $\mathrm{Fe}$ in ferrous carbonates, whereas substitution by $\mathrm{Ca}$ is limited, and $\mathrm{Fe}$ - and $\mathrm{Ca}$-carbonates are often reported to exist as separate phases (Suess, 1979; Curtis et al., 1986). Unit cell dimensions and d-spacings are generally linearly related to composition (Brown, 1980). For instance, mixed carbonates of $\mathrm{Ca}-\mathrm{Mn}-\mathrm{Mg}$ will give $\mathrm{d}(104)$-spacings intermediate between those of the end members calcite (3.03 A), magnesite (2.74 A) and rhodochrosite (2.84 A).

The carbonate in the Lake Åsa sediment has a $\mathrm{d}(104)$-spacing in the range 2.94-2.90 A. Upon heating of the samples, $\mathrm{CO}_{2}$ typically evolves in two steps within the temperature range 600$850{ }^{\circ} \mathrm{C}$, both possibly related to the decomposition of carbonate. While being slowly dissolved in cold acid, the carbonate readily dissolves in warm hydrochloric acid and in the unbuffered, oxidizing $\mathrm{H}_{2} \mathrm{O}_{2}$-solution. Allocation of $\mathrm{Fe}, \mathrm{Mn}, \mathrm{Ca}$ and $\mathrm{Mg}$ in this solution to the carbonate phase gives an average composition corresponding to that of an ankerite, $\left(\mathrm{Ca}_{0.50} \mathrm{Mg}_{0.31} \mathrm{Fe}_{0.18} \mathrm{Mn}_{0.01}\right) \mathrm{CO}_{3}$, i.e. a Ca-Mg-carbonate with a considerable substitution of $\mathrm{Mg}$ by $\mathrm{Fe}$. Most observations of ankerite are made in ancient, non-marine sediments, though it has been reported to form also in Holocene lake sediments (Jörstad et al., 1982). It cannot be excluded, however, that the extracted $\mathrm{Fe}$ is derived from a separate Fe-carbonate, the amount of which would be too low to detect by the XRD-analysis. In addition, $\mathrm{Sr}$ and $\mathrm{Zn}$ may occur as trace constituents in the carbonate, as suggested by their strong correlations $(r=0.92-$ 0.95 ) to both $\mathrm{Ca}$ and $\mathrm{Mn}$.

Ferrous carbonates form under reducing conditions in non-sulphidic sediments during an early stage of diagenesis related to the decomposition of organic matter. Once the dissolved oxygen is consumed, organic diagenesis in the absence of sulphate can proceed along a pathway, which involves production of methane and carbon diox- ide. Other possible oxidants of organic matter are nitrate, Mn(III)-(IV) and Fe(III) minerals, which are being reduced in the sequence mentioned (Berner 1981).

Isolation of the Lake Åsa basin from the atmosphere due to ice-cover and bottom-freezing over long periods could easily explain that conditions developed in favor of this series of redox reactions already at shallow depth in the sediment. Constricted exchange with the atmosphere led to rapid consumption of oxygen, and $\mathrm{CO}_{2}$, produced on decomposition of organic matter, could accumulate in the sediment in more than atmospheric amounts. The combined effect of all reactions is a net increase in alkalinity, which favors carbonate precipitation (e.g. Boström, 1967; Berner, 1971; Curtis et al., 1986). Moreover, the presence of volcanic glass in the sediment is most likely a significant $\mathrm{pH}$-controlling factor, maintaining $\mathrm{pH}$ at a high level.

Since the inorganic carbon content could not be determined for all samples, the carbonate content (Fig. 8) has been estimated by allocation of $\mathrm{Ca}, \mathrm{Mg}, \mathrm{Fe}$ and $\mathrm{Mn}$ to a carbonate phase. The equivalence between the inorganic carbon content and the molar sum of these cations is fairly good in those samples having both data sets available.

The carbonate content is positively correlated $(r=0.75)$ to the organic content, a fact which can be explained by the suggested model for carbonate precipitation. The presence of carbonate generated during methanogenesis could also, in part, explain the high $\delta^{13} \mathrm{C}$-values of the bulk sediment (Table 2), since bicarbonate formed in connection to this process tends to be enriched in heavy isotopes (Curtis et al., 1986).

Despite cation preferences and partitioning effects during crystallization (Curtis et al., 1986; Lumsden et al., 1989), the carbonate composition can be expected to have some relation to the pore water chemistry at the time of carbonate precipitation. The relative proportions of cations of the carbonate are illustrated by the $\mathrm{Fe} / \mathrm{Mn}$ and $\mathrm{Mg} / \mathrm{Ca}$ ratios in Fig. 8.

Under naturally occurring $\mathrm{pH}-\mathrm{Eh}$ conditions, $\mathrm{Fe}(\mathrm{II})$ is more easily oxidized than $\mathrm{Mn}(\mathrm{II})$ and 
iron compounds are generally less soluble than the corresponding manganese compounds (Garrels \& Christ, 1965). Mobilization from the sediment, and hence, pore water concentrations of $\mathrm{Fe}$ and $\mathrm{Mn}$ will therefore be affected in a predictable way by movements of the oxic/anoxic boundary in the sediment-water column.

Based on trends in the $\mathrm{Fe} / \mathrm{Mn}$ ratio, the following four intervals may be distinguished in the sediment sequence:

4700-3300 BP: $\mathrm{Mn}$ and, in particular, $\mathrm{Fe}$ increase, giving a trend of steadily increasing $\mathrm{Fe} / \mathrm{Mn}$ ratio, which accompanies the upward increase in the organic content. Over the same period, the organic matter appears to be gradually more dominated by juvenile compounds (cf. the $\mathrm{C} / \mathrm{N}$ ratio in Fig. 6). The simple explanation of the $\mathrm{Fe} / \mathrm{Mn}$ trend may be that mobilization, and subsequent precipitation, of $\mathrm{Fe}$ in the sediment was intensified when the quantity as well as the quality of the reducing substances, i.e. organic matter, changed.

3300-2900 BP: The Fe/Mn-ratio drops at the lower boundary, due to a lowering of the Fecontent. The organic content is still increasing. Biological data, showing very high influx values for pollen and spores of terrestrial species and high values for light-demanding Pediastrum, indicate that the lake was ice-free over longer periods. The organic matter in this interval is characterized by high $\mathrm{C} / \mathrm{N}$ values (Fig. 6), which may be an effect of increased input of aerobically decomposed organic matter from the drainage area. Alternatively, an improved replenishment of oxygen in the surface sediment allowed the most reactive fraction of the organic matter to be decomposed aerobically before burial. As a result, the 'reducing power' of the more refractory organic matter being buried may have been insufficient to reduce large amounts of $\mathrm{Fe}$. The data thus suggest that, despite a higher input of organcic matter, conditions were less reducing in the sediment than before, possibly as a result of longer ice-free summers.

$2900-2500 \mathrm{BP}: \mathrm{Fe} / \mathrm{Mn}$ ratios are variable and shift between extreme values, with minima located at the organic-poor ash-layers. The interval is characterized not only by variable organic contents but also by drastic grain-size changes. The effects of porosity variations on the diffusional transport may have had a large influence on how details in the $\mathrm{Fe} / \mathrm{Mn}$ pattern developed. However, an overall high organic content, in combination with biological data, indicate that conditions remained at an optimum for organic productivity in and/or around the lake. During this period, sedimentation rates increased drastically (cf. Fig. 6). A rapid burial of the organic matter should oppose any effect on organic diagenesis of improved oxygenation in the surface sediment, and can explain the low $\mathrm{C} / \mathrm{N}$ ratio of the organic matter in this interval. Peaks in the $\mathrm{Fe} / \mathrm{Mn}$ ratio may therefore reflect strongly reducing conditions in the sediment when high amounts of immature, organic matter was decomposed.

2500-800 BP: Most data indicate that conditions were stabilized during this period, but the $\mathrm{Fe} / \mathrm{Mn}$ ratio has a distinct trend of decreasing values towards the surface. The Fe-content is low also in absolute terms and Fe is 'replaced' upwards mainly by $\mathrm{Mg}$, resulting in a systematic increase in the $\mathrm{Mg} / \mathrm{Ca}$ ratio towards the surface (Fig. 8). The change in composition is probably determined by factors other than redox conditions.

Fig. 9 shows the distribution of some elements, extracted by treatment with acid hydroxylamine hydrochloride solution. It is evident from XRDanalysis of samples, which have passed through this extraction, that some dissolution occurs of the most fine-grained minerals, mainly chlorite and smectite. This is best seen by the increase of the quartz peaks and the simultaneous decrease of the 14 (chlorite + smectite) and $7 \mathrm{~A}$ (chlorite) peaks in the diffractogram of Fig. 7. The ease with which the minerals dissolve, indicates that their iron content is relatively high (Brown \& Brindley, 1980 ), but dissolution will release, in addition to $\mathrm{Fe}$, also some $\mathrm{Mg}, \mathrm{Al}$ and $\mathrm{Si}$ to the solution (chemical data in Newman \& Brown, 1987). It is seen in Fig. 8 that the content of $\mathrm{Mg}$, besides $\mathrm{Si}$, in the acid soluble phase(s) increases in the upper half of the section, where a higher smectite/ 


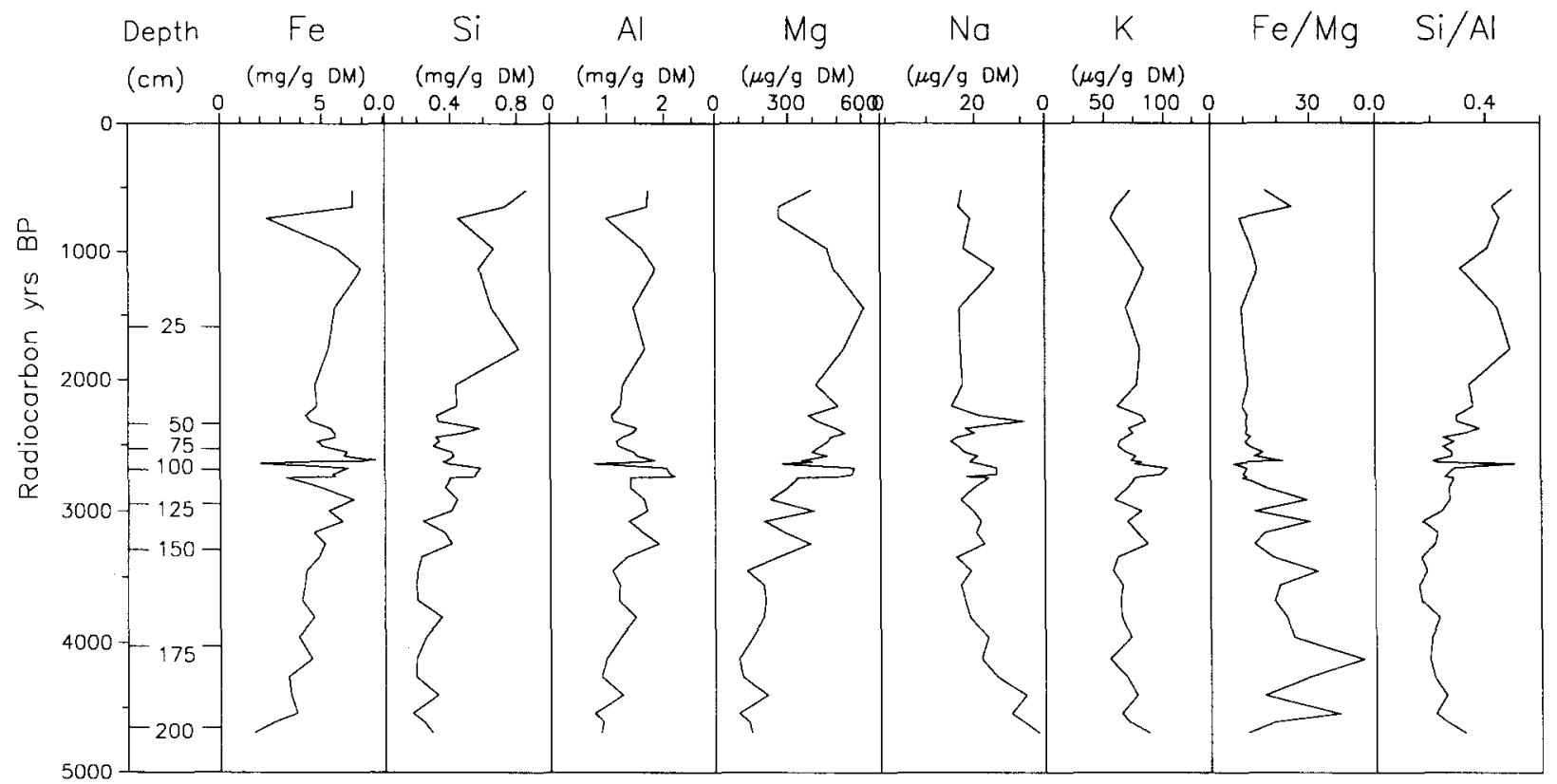

Fig. 9. The stratigraphic distribution of some elements, extracted into $25 \%$ acetic acid +1 M hydroxylamine hydrochloride solution.

chlorite ratio is suggested by the XRD-data. The chemical data are consistent with an increase of, preferably $\mathrm{Mg}$-rich, smectite relative to $\mathrm{Fe}$ chlorite. Variations in mineralogy may reflect various stages of alteration in a sediment, which has derived much of its minerogenic matter from different generations of volcanic ash. A high abundance of $\mathrm{Mg}$-minerals of relatively low stability has likely supported high levels of $\mathrm{Mg}$ in the pore solution, thereby favoring precipitation of $\mathrm{Mg}$ rich carbonates in the youngest sediment.

The amount of Si extracted into weak alkaline solutions has often been used to estimate the content of biogenic forms of silica (e.g. Digerfeldt 1972; Renberg 1976; Engstrom \& Wright 1984). However, any possible variations in the biogenic silica content (Fig. 8) are entirely masked by variations in easily soluble inorganic Si-sources. Thus maximum concentrations of $\mathrm{Si}$ are invariably found at those intervals, which have a high content of volcanic ash and are poor in diatoms. The inorganic source of $\mathrm{Si}$ is indicated also by significant amounts of, for instance, $\mathrm{Al}$ and $\mathrm{Fe}$ in the alkaline extract. The amorphous silica strati- graphy is therefore assumed to be a signal of the input of ash rather than of the diatom frequency in the sediment. However, increased levels of reactive silica-compounds after an input of tephra would probably favor the production and/or preservation of biogenic forms of silica.

\section{Diatom assemblages}

36 samples were analysed and 92 diatom taxa were identified (see Appendix). The diatoms found are typical of freshwater conditions and are indifferent (with some exceptions) to salinity. As can be seen in Fig. 10, indifferent and alkaliphilous forms dominate throughout the whole profile; only very few acidophilous forms were found. With the exception of Fragilaria crotonensis Kitton, a species often considered to be planktonic, there are no real planktonic taxa present which makes a life-form grouping unnecessary. Most of the taxa found are cosmopolitan.

In order to understand the diatom assemblages some special environmental factors have to be 


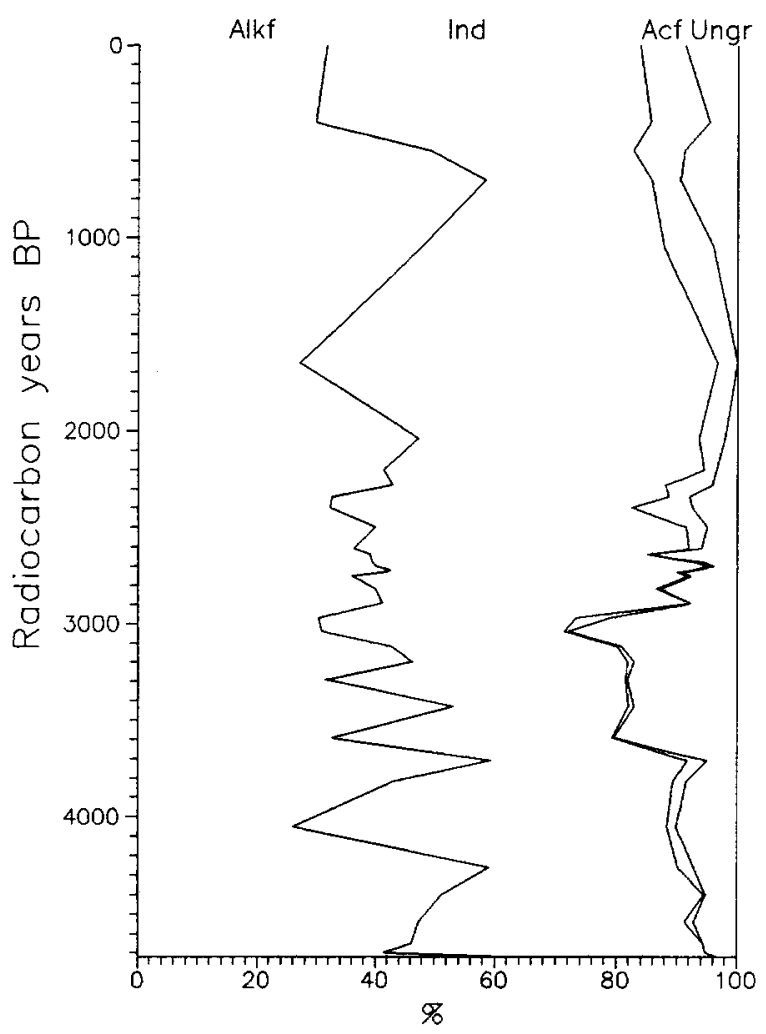

Fig. 10. Diagram showing the relationship (in $\%$ ) between alkaliphilous, indifferent, acidophilous, and ungrouped diatoms in 'Lake Asa'.

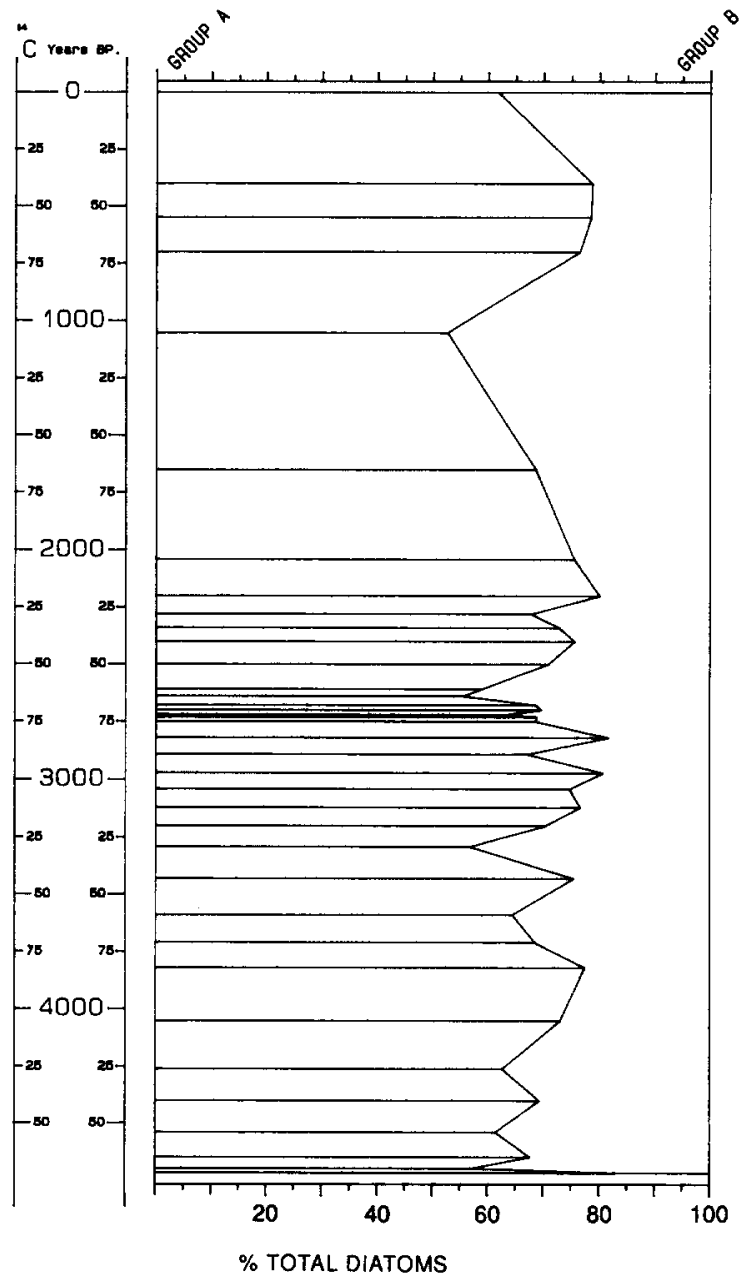

Fig. 11. Diagram showing the relationship (in $\%$ ) between aerophilic, eu-terrestrial, and bryophytic diatoms (Group A) and other periphytic diatoms (Group B).

\section{Information about habitat and ecology of some of the} taxa

Besides the well known aerophilic diatoms, such as Hantzschia amphioxys (Ehrenbg.) Grun., Melosira roseana Rabenhorst, Pinnularia borealis Ehrenbg., Luticola mutica (Kütz.) D.G. Mann, and its varieties, Luticola cohnii (Hilse) D.G. Mann, and Diadesmis contenta (Grun.) D.G. Mann and its forma biceps (Arnott) D.G. Mann, we will here discuss some abundant species in 'Lake Åsa' that might be found in aerial environments. 
Achnanthes exigua Grunow is sensitive to high $\mathrm{pH}$ fluctuations, needs high $\mathrm{O}_{2}$ concentrations (Cholnoky, 1968), and is found in waters with $\mathrm{pH}$ 7.0-7.6 (Salden, 1978; Schlüter, 1961). Hustedt (1934, 1942), Schlüter (1961), and Hickman \& Vitt (1973) classified A. exigua as a littoral form, found on mosses. Also $A$. lanceolata (Bréb.) Grunow is found on mosses (Krieger, 1933; Hustedt, 1934; Krasske, 1932; Hickman \& Vitt, 1973), as well as in soils (Petersen, 1935; Brendemühl, 1950; Round, 1965; Schwabe, 1970). This wide range of ecological and habitat information in the literature can possibly depend on identification differences, which is well shown in the discussion around the Achnanthes lanceolatacomplex in Lange-Bertalot \& Krammer (1989).

Achnanthes minutissima Kützing is a common and widespread diatom thriving in freshwater with a pH of 7.5-7.8 (Cholnoky, 1968), but can be found on mosses (Beger, 1927; Krasske, 1932; Lund, 1946; Brendemühl, 1950; Bock, 1963) and on soils (Schwabe 1970), but considered by Petersen (1935) as hydrophytic-pseudoaerial.

The names $A$. delicatula (Kütz.) Grunow and A. linkei Hustedt are 'linked' together (Fig. 12) due to the taxonomical difficulties discussed in Krammer \& Lange-Bertalot (1991b). Both taxa are considered to be brackish water species (Hustedt, 1938; Cholnoky, 1968). Andrews (1981) provides a detailed SEM investigation of this relatively poorly known taxon. He reported it from Pleistocene sediments as well as from 'a few coastal localities that have cool-temperate waters'.

Achnanthes delicatula (Kütz.) Grunow was found by Petersen (1928) in a mountain cave at a height of $20 \mathrm{~m}$ together with true freshwater species, other brackish water species and also terrestrial forms. It has been discussed in the literature and has been stated that halophilous and mesohalobous species are found in the supralittoral of sea coasts (Simonsen, 1962; Hustedt, 1957), which is an aerial biotope in the splashwater zone (Florin, 1970). Well-oxygenated, alkaline freshwater stimulates the occurrence of these brackish water species (Hustedt, 1934, 1957; Cholnoky, 1960; Simonsen, 1962). Florin
(1970) stated that 'light is here of more importance than oxygen'. Schwabe (1970) means that the aerophilous diatoms have broader ecological ability to develop in both fresh- and saltwater. This is also found by Hustedt (1957), Cholnoky (1968), and Simonsen (1962). Because of the taxonomical uncertainty of both the here mentioned taxa, we 'linked' both names in the diagram.

Punctastriata pinnata var. lancettula (Schuman) Williams \& Round, a diatom found in freshwater with a $\mathrm{pH}$ around 7.6-7.8, can survive fluctuations in osmotic pressure and needs water rich in oxygen (Cholnoky, 1968). It is found on mosses (Hustedt, 1942), but also in soils (Schwabe, 1970). Salden (1978) found it as an epiphyte on Nitella.

Round (1968) is of the opinion that Fragilaria crotonensis Kitton needs high $\mathrm{SiO}_{2}$-concentrations to be able to develop. High abundance of this species is found in association with high phosphate concentrations (Bernhardt etal., $1970)$. Engstrom et al. (1985) report that $F$. crotonensis possibly responds to nutrient increase from different sources, including soil erosion.

\section{Description of the diatom succession}

The diatom species composition fluctuates greatly throughout the sequence, which has made it difficult to zonate the diatom assemblages. However, an attempt is made based on three different diagrams: 1) the main diagram where the 31 most common diatoms are included. Punctastriata pinnata var. lancettula (Schuman) Williams \& Round, Fragilaria vaucheriae (Kütz.) Petersen and $F$. capucina Desz. are excluded from the diatom sum (Fig. 12); 2) a diagram where the species are amalgamated to yield generic totals (Fig. 13), and 3) a diagram of the taxa considered to be aerophilic, eu-terrestrial or bryophytic and other periphytic diatoms (Fig. 11). Five main zones are distinguishable.

Zone 1, 4700-4600 BP: This zone includes the lowermost three samples, where Achnanthes exigua, A. lanceolata var. lanceolata together with Navicula capitata var. hungarica (Grun.) Ross and Nitzschia perminuta (Grun.) M. Peragallo are 


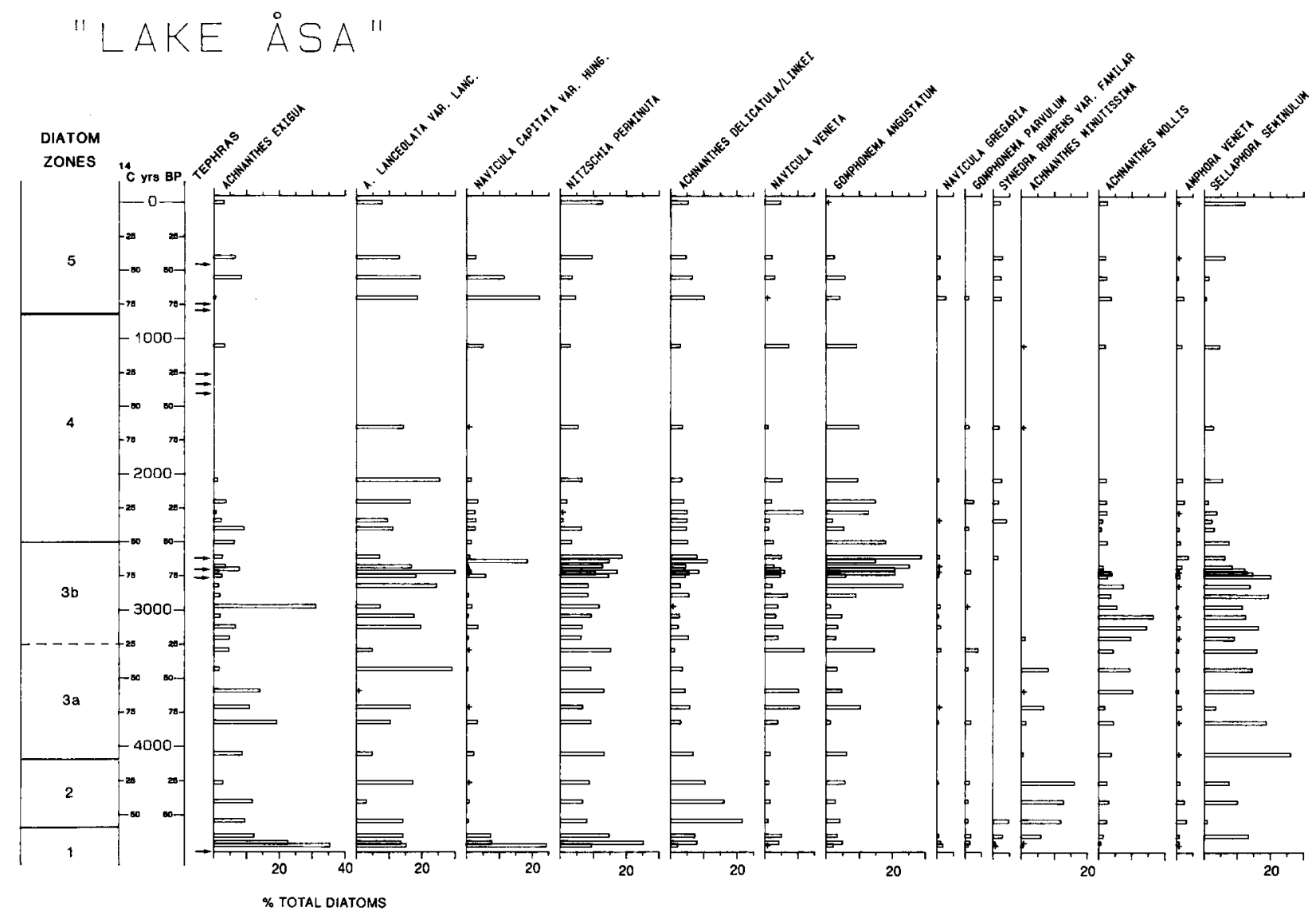

dominant. They all become less dominant in zone 2.

Zone 2, 4600-4100 BP: Decreasing frequencies of Achnanthes exigua, Navicula capitata var. hungarica, and $N$. veneta Kützing are replaced by increasing percentages of Achnanthes linkei/A. delicatula, A minutissima, and Sellaphora seminulum (Grun.) D. G. Mann. Achnanthes lanceolata var. frequentissima sensu Lange-Bertalot \& Krammer (1989) reaches a high value of $20 \%$ at 4300 BP. Most striking are, however, the high values (50-60\%) of Punctastriata pinnata var. lancettula.

Zone 3, 4100-2500 BP: Zone 3 is the most complex of the five distingushed diatom zones. It can be characterised as having no typical diatom assemblage, but in this rather 'chaotic' diatom stratigraphy, we think it is possible to distinguish two different zones, subzones $3 \mathrm{a}$ and $3 \mathrm{~b}$. Sub- zone $3 \mathrm{a}(4100-3250 \mathrm{BP})$ is characterised by a number of species with increasing frequencies: Achnanthes exigua, A. lanceolata var. lanceolata, A. renei, A. mollis, Nitzschia perminuta, and Navicula (Sellaphora) seminulum. Several species, such as e.g. Gomphonema angustatum, Navicula veneta, Achnanthes minutissima, Nitzschia frustulum, Stauroneis anceps var. anceps and var. hyalina are characterized by fluctuating values, which is also the case with Punctastriata pinnata var. lancettula. The main characteristic features of subzone $3 \mathrm{~b}$ (3250-2500 BP) are the highly fluctuating values of many of the taxa, and the fact that Achnanthes minutissima more or less disappears. The middle part of this zone is dominated by Achnanthes and to some degree Navicula species (Fig. 13), while the upper part is dominated by Nitzschia, Gomphonema, and Stauroneis species. In the uppermost samples, the values for 


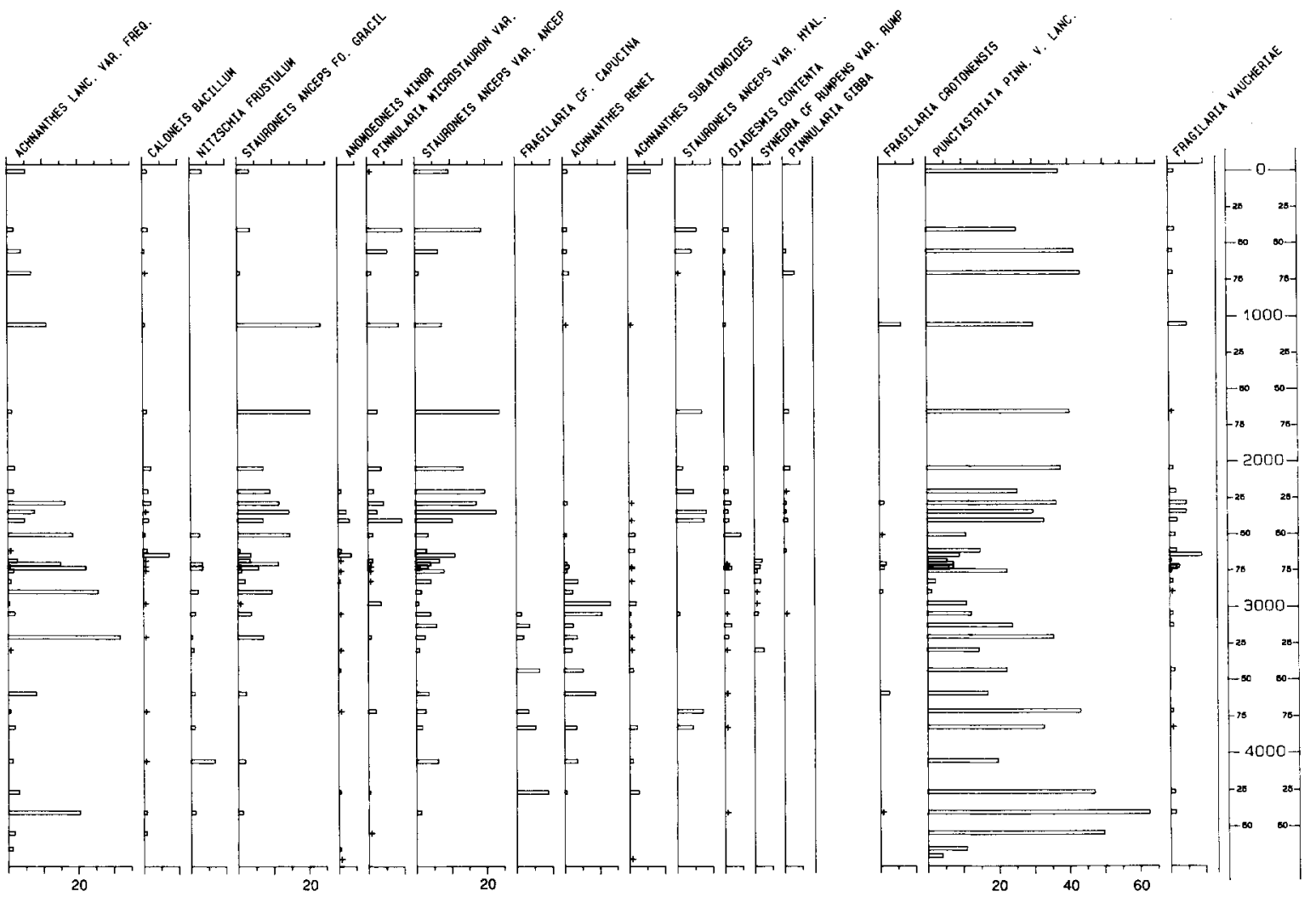

Fig. 12. The main diatom diagram, presenting the 31 most common taxa related to chronology. The diatom sum, excluding the three taxa to the right, varied between 300 and 550. The arrows to the left indicate the tephra layers.

Amphora, Anomoeoneis, Pinnularia, Caloneis, and Aulacoseira species increase markedly. 'Fragilaria' (sensu Hustedt) species fluctuate throughout the zone.

Zone 4, 2500-800 BP: This zone is dominated by Stauroneis species ( $S$. anceps var. anceps, $S$. anceps var. hyalina, and $S$. anceps fo. gracilis). In the lower half of the zone, Achnanthes lanceolata var. lanceolata is also quite abundant, while other Achnanthes species decrease markedly. Apart from the Stauroneis species, the upper part of the zone is dominated by Punctastriata pinnata var. lancettula.

Zone 5, 800-0 BP: Increasing frequencies of Achnanthes species, especially Achnanthes lanceolata var. lanceolata, $A$. delicatula/linkei, and Achnanthes exigua, are typical for this zone. Navicula capitata var. hungarica, and Nitzschia per- minuta again occur with higher percentages, whereas Stauroneis taxa have very low percentages in the beginning but increase in the uppermost samples.

Most of the diatoms present in this investigation have also been found in other Antarctic lakes (Pankow et al. 1987, Oppenheim \& Ellis-Evans, 1989; Oppenheim, 1990; Oppenheim \& Greenwood, 1990; Schmidt et al., 1990; Björck et al., 1991a; Hansson \& Håkansson, 1992), but the species composition seems different in every lake. In the lakes so far investigated, some tendencies in lake development could be recognized (Schmidt et al., 1990; Björck et al., 1991a; Wasell \& Håkansson, 1992). In the discussion below the diatoms and their succession help to elucidate the development of the lake. 

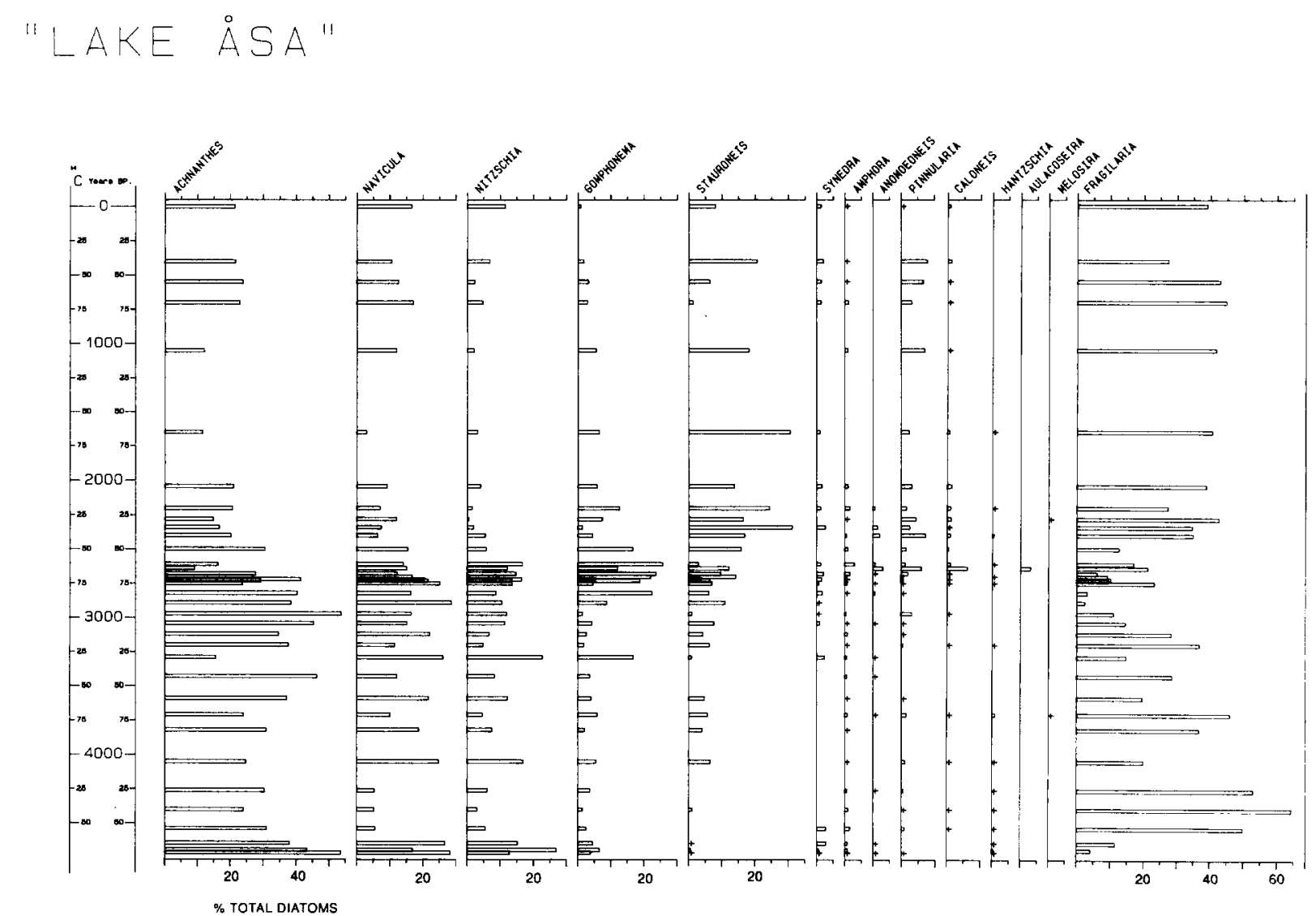

Fig. 13. A diatom diagram where the different species are included under their respective generic names.

\section{Pollen, spore and Pediastrum stratigraphy}

The strenuous work in preparing and analysing samples for their pollen and spore content has resulted in a combined pollen, spore, and Pediastrum diagram. Since we regard the influx changes as being more significant for environmental changes than the relative proportion between grain types, we present our data as an influx diagram (Fig. 14). Another reason is that the percentages for most pollen and spore types would be very low. The influx estimations are based on the age/depth curve (Fig. 5), and the influx of each sample is based on the mean accumulation rate between the preceding and following sample level, i.e. a sediment sequence of $5-17.5 \mathrm{~cm}$. The high and possibly variable accumulation rates during, between, and after the in- tense tephra depositions between 121 and $89 \mathrm{~cm}$ caused some problems. The mean rate of those 32 $\mathrm{cm}$, excluding the pure tephras, is $2.4 \mathrm{~mm} / \mathrm{yr}$, and the rate slightly after the $91-89 \mathrm{~cm}$ tephra (AP10 in Table 3) is $2.6 \mathrm{~mm} / \mathrm{yr}$. This latter estimation is based on counting possible annual laminae in layer 17 (Table 1). Based on these calculations, the following presumptions are made about the accumulation rates for samples that are presumed to have been affected by the tephra fall-outs AP12-AP10: samples directly deposited after an ash fall-out have rates of $3 \mathrm{~mm} / \mathrm{yr}$, for samples in-between tephras the rate is $2 \mathrm{~mm} / \mathrm{yr}$, and in samples deposited just before a tephra the rate is $1.5 \mathrm{~mm} / \mathrm{yr}$. With these assumptions, the mean accumulation for the sequence in question became $2.4 \mathrm{~mm} / \mathrm{yr}$. Only sample no. 16 from the top (dated to $2630 \mathrm{BP}$ ) was sampled in pure tephra, 

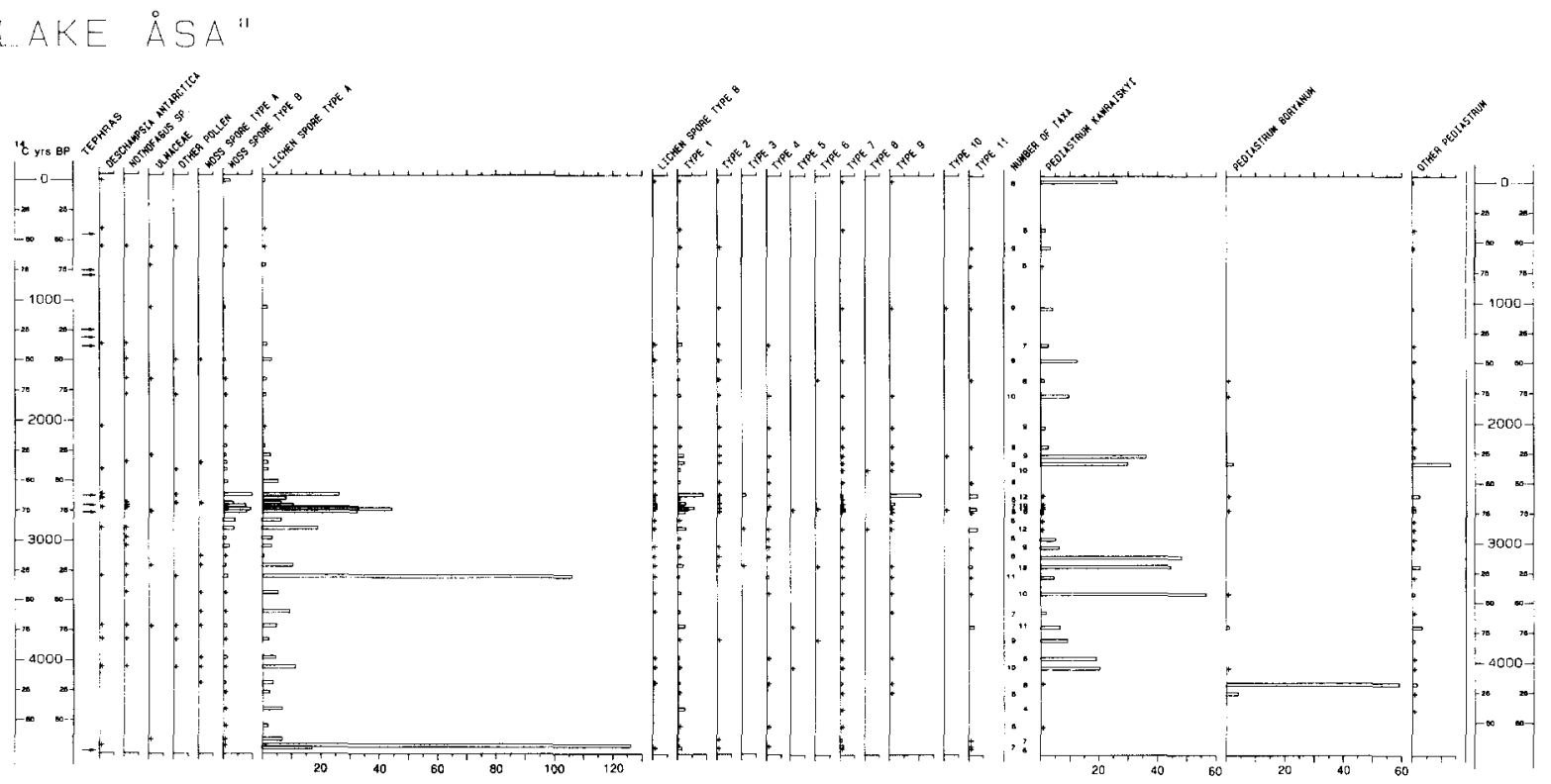

Fig. 14. An influx diagram of the different pollen, spore, and Pediastrum types found in 'Lake Åsa' related to chronology. The different unidentified types are described in the text and some are shown in Fig. 3. The arrows to the left indicate the tephra layers.

but its influx value was assumed to be $3 \mathrm{~mm} / \mathrm{yr}$, although the actual rate probably is significantly higher. How high is, however, very difficult to estimate. In any case, it means that its actual influx value should possibly be larger than shown in Fig. 14.

A few spore types completely dominate the diagram. Lichen spores of type A (Usnea?) are most abundant, together with moss spores of type B. Apart from those, types 1, 9, and 11 are most common. The pollen types found exhibit very low influx values. With regard to the two Pediastrum types distinguished, the Pediastrum boryanum type is common around $4300 \mathrm{BP}$, while the Pediastrum kawraiskyi type occurs with relatively high values from ca $4100 \mathrm{BP}$ up to the top of the core, with maximum values at $3300-3100$ BP. The only period with very low values occurs between 2900 and 2400 BP (Fig. 15).

Instead of a zonation of the diagram, we will here try to describe the most prominent features and changes of this combined spore and pollen stratigraphy. The lowermost part, 4700-4000 BP, is dominated by lichen spores type A with a dis- tinct peak at $4700 \mathrm{BP}$. Other types that occur are moss spores of type B, type 1 , and type 7 (Fig. 15). Except for the distinct 4700 BP peak, the total influx is fairly moderate.

Between 4000 and 2800 BP the same types dominate with some additional types such as lichen spores of type B, and Nothofagus pollen. A very marked peak of lichen spores of type A occur at $c a .3300 \mathrm{BP}$, which coincides with relatively high values of moss spores of type $B$, and type 4 and low values of Pediastrum kawraiskyi. Except for the peak at $3300 \mathrm{BP}$, the total influx varies around 1000 grains $/ \mathrm{cm}^{2} / \mathrm{yr}$.

The time period $2800-2550 \mathrm{BP}$ is characterized by the most significant changes. The following types reach their maximum values during this time: Deschampsia antarctica, Nothofagus, moss spores of type B, lichen spores of type A, lichen spores of type B, type 1 , type 2 , type 3 , type 4 , type 5 , type 7 , type 9 , type 10 , and type 11 . At the same time Pediastrum kawraiskyi attains very low values. Total influx values are very high.

Between 2500 and the top of the core the changes are in general only minor, although the 


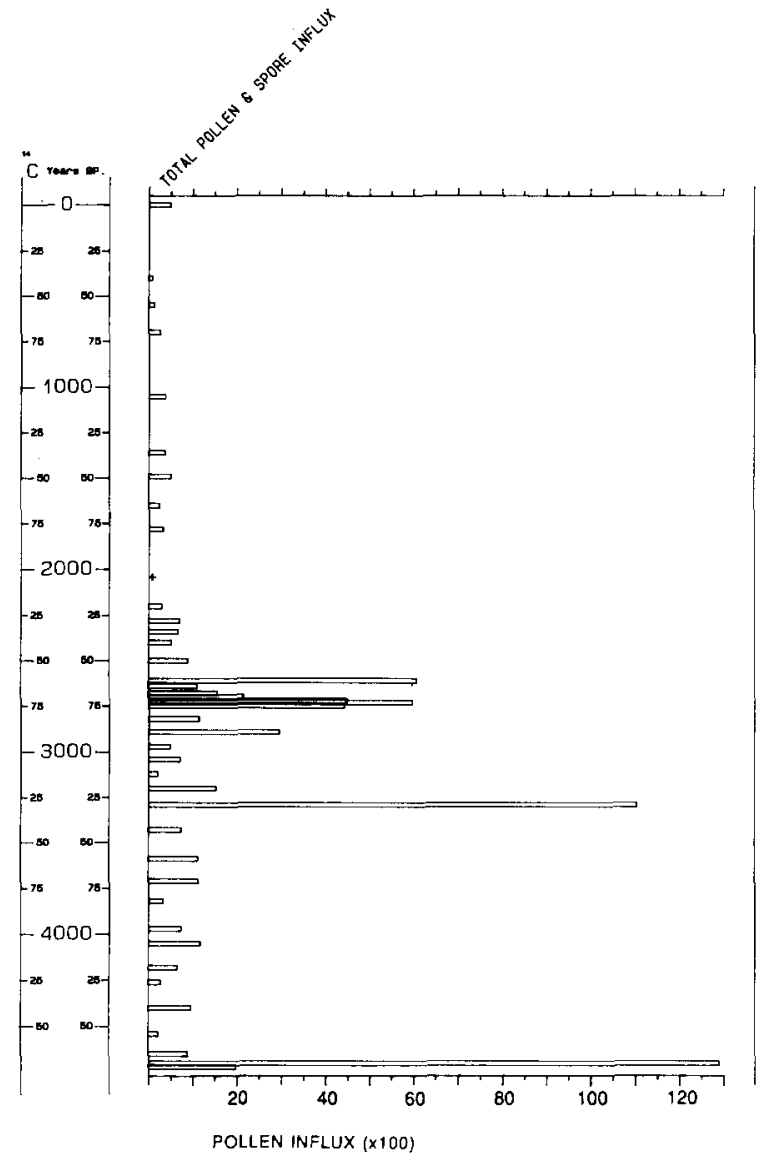

Fig. 15. Diagram showing the total influx of pollen and spores.

period 2000-1500 BP is characterised by a slight increase of most of the types, including Pediastrum kawraiskyi. Total influx values decrease between 2500 and 2000 BP. A small peak (500 grains $/ \mathrm{cm}^{2} / \mathrm{yr}$ ) is attained at $1400 \mathrm{BP}$, but in general the influx values reach their overall lowest frequencies from $2500 \mathrm{BP}$ up to the present. Pediastrum values reach a peak in the recent sample.

\section{Moss assemblages}

Between 4600 and 3300 BP the moss assemblages indicate a relatively deep-water environment, both based on the species composition and the modification of the fragments.
Although the deep-water moss component is dominant throughout most of the sequence, there is, however, some input of terrestrial populations (Bryum, Brachythecium, and Dicranoweisia) between 3300 and 2700 BP. The occurrence of these terrestrial species is the most striking change in the moss stratigraphy. Usually these genera and/or species are rare as aquatics. The presence of these terrestrial populations in the middle of the lake suggest that a high-energy environment must have been present in the watershed to be able to wash these species into the lake.

The upper half of the sequence, 2700-0 BP, is almost completely barren of moss remains and only one sample, dated to $1650 \mathrm{BP}$, was analysed from the uppermost meter. Its moss assemblage is similar to the assemblages in the older samples, indicating calmer conditions in a relatively deepwater environment.

\section{Multivariate analysis}

In order to structure and better understand this large and complex data set, multivariate statistical techniques were required. For this purpose the CANOCO programme (Ter Braak, 1988) has been used. The data were analysed with a variety of multivariate techniques (PCA, DCA, RDA, $\mathrm{CA}, \mathrm{CCA}$ ) to find patterns and relationships in each of the different data sets as well as between the data sets.

All data sets, except the moss stratigraphy, were analysed with PCA and/or CA. These analyses resulted in zonations (by samples/time) of each data set that turned out rather similar between the different records. All different parameters analysed were then put together into one data set. Within each data set the values were standardised. The standardization followed two principles: a) the mathematical relationships within each data set was maintained; and b) maximum individual values of each data set must be $>10^{2}$ and $<10^{3}$. As a corollary of these analyses, the sequence was divided into eight time periods: $4700-4600,4600-4000,4000-3300,3300-2800$, $2800-2500,2500-2000,2000-1400$, and 1400-0 
BP. This made it possible to reduce the number of samples from 45 to 8 (time periods). The number of variables was, however, too high ( $c a .50$, excluding the diatom taxa) to obtain a clear picture of the environmental development. For this reason, a careful selection of the statistically most important variables as well as the most possible environmentally sensitive variables (see above) were picked out: annual accumulation rates for 1) lichen spores, 2) other spores, 3) Deschampsia antarctica, 4) long distance transported pollen grains, 5) Pediastrum kawraisky, 6) C, 7) Fe, 8) P, 9) $\mathrm{N}, 10$ ) amorphous $\mathrm{Si}$, and 11) the sediment. Percentage values of 12) alkaliphilous, and 13) acidophilous diatoms were also picked out. The following chemical ratios were considered most useful: 14) $\mathrm{C} / \mathrm{N}, 15) \mathrm{Mg} / \mathrm{Ca}, 16) \mathrm{Fe} / \mathrm{Mn}, 17) \mathrm{Cu} /$ $\mathrm{Zn}, 18) \mathrm{Fe} / \mathrm{P}$-tot, 19) Si/Al, and 20) $\mathrm{Mn} / \mathrm{Mg}$. Finally the ratio between clay/sand-coarse silt was also included. After this 'simplification' of the data set, it comprises eight time periods with 21 variables. The mean value for each variable was calculated for every time period. This procedure not only simplifies the records, but also smooths out extreme values.

The aim of the multivariate analysis was to find a set of environmentally related and defined var- iables that can explain much of the variance in the data set. When a set of variables was chosen to be the predictor explanatory environmental variables, the gradient length of the remaining response variables had to be checked through detrended correspondence analysis (DCA), detrending by segments and downweighting of rare variables. This was performed to control whether to use redundancy analysis (RDA) or canonical correspondence analysis (CCA) in the next step of the analysis (Ter Braak \& Prentice, 1988). All DCA runs resulted in gradient lengths of less than 2 standard deviations, which implies the use of RDA (Ter Braak, 1988). In the RDA the correlation matrix option was chosen since the variables are in different units, and the scaling was made on a correlation biplot. The RDA results were evaluated by checking the $t-v a l u e s$ of the canonical coefficients and the inter-set correlations of the selected environmental variables (Tables 5 and 6). They should be higher than 2.1 (Ter Braak, 1988) and/or more than ca. 0.5-0.6, respectively. Numerous combinations of 'environmental variables' were tested before six statistically significant predictor explanatory environmental variables were found among the 21 variables chosen (Fig. 16 and Table 5). During

Table 5. A. Inter-set correlations of the selected environmental variables with axes, and B. t-values of canonical coefficients when the data set is analysed with RDA (see text and Fig. 16).

\begin{tabular}{lcrrr}
\hline A. & Axis 1 & Axis 2 & Axis 3 & Axis 4 \\
\hline Eigenvalues & 0.38 & 0.29 & 0.15 & 0.05 \\
Sed rate (Humid, erosion) & 0.94 & -0.27 & 0.15 & 0.00 \\
Amorphous Si (Volcanic input) & 0.66 & 0.72 & -0.18 & -0.10 \\
C acc (Organic inwash) & 0.74 & 0.4 & -0.37 & 0.34 \\
Acidophilous diatoms (Lowered pH) & -0.48 & -0.37 & 0.21 & 0.23 \\
Long dist poll (Mild, humid) & 0.43 & -0.82 & 0.30 \\
Fe/Mn (Anoxic) & -0.31 & -0.66 & 0.53 \\
\hline
\end{tabular}

B.

\begin{tabular}{|c|c|c|c|c|}
\hline Sed rate (Humid, erosion) & 2.53 & 1.90 & 1.38 & 0.29 \\
\hline Amorphous Si (Volcanic input) & 2.12 & -2.14 & -1.38 & -0.28 \\
\hline $\mathrm{C}$ acc (Organic inwash) & -0.94 & 2.37 & 1.15 & 0.97 \\
\hline Acidophilous diatoms (Lowered $\mathrm{pH}$ ) & 3.81 & -2.93 & -1.45 & 1.27 \\
\hline Long dist poll (Mild, humid) & 1.08 & -2.56 & -1.35 & -0.50 \\
\hline $\mathrm{Fe} / \mathrm{Mn}$ (Anoxic) & 1.04 & -2.79 & -1.24 & 1.25 \\
\hline
\end{tabular}


Table 6. A. Inter-set correlations of the selected environmental variables with axes, and $\mathrm{B}$. $\mathrm{t}$-values of canonical coefficients when the data set is analysed with RDA excluding the two volcanic periods (see text and Fig. 17).

\begin{tabular}{lrrrr}
\hline A. & Axis 1 & Axis 2 & Axis 3 & Axis 4 \\
\hline Eigenvalues & 0.34 & 0.29 & 0.14 & 0.09 \\
C/N (Aerobic) & 0.62 & 0.71 & -0.19 & -0.23 \\
Si/Al (Diagenetic) & -0.87 & -0.34 & 0.25 & -0.21 \\
Clay/sand (Calm, arid) & -0.57 & -0.79 & -0.10 & -0.19 \\
Long dist pollen (Mild, humid) & 0.23 & -0.82 & 0.49 & -0.10 \\
\hline
\end{tabular}

B.

\begin{tabular}{|c|c|c|c|c|}
\hline $\mathrm{C} / \mathrm{N}$ (Aerobic) & 1.68 & 1.11 & -0.30 & -4.79 \\
\hline $\mathrm{Si} / \mathrm{Al}$ (Diagenetic) & -4.03 & 2.97 & 2.90 & -2.70 \\
\hline Clay/sand (Calm, arid) & 0.45 & -3.47 & -3.51 & -2.37 \\
\hline Long dist poll (Mild, humid) & 4.34 & -2.71 & 3.35 & -1.96 \\
\hline
\end{tabular}

the course of the repeated tests of combinations, it was obvious that the tephra input dominates the variance within the data set, although the pure tephra samples were omitted all through the analyses. This was one main reason for the difficulty to find several strong variables that are more-orless independent of the tephra influence. Although we think that Fig. 16 well illustrates the development in and around 'Lake Åsa', we decided to try to reveal the underlying, more subtle pattern by excluding the two time periods with most substantial tephra influence: $4700-4600$ and $2800-$ 2500 BP. This strongly reduced tephra impact made the search for strong environmental variables (Table 6), in different 'directions', relatively easy compared to the previous numerous test analyses.

\section{Discussion}

It is evident that the tephras are responsible for the major variance in the data sets. The frequent tephra fall-outs from Deception Island have thus had such a significant influence on the development of the lake and its catchment that almost all other influences have become of secondary importance. The reasons for this large tephra impact on the lake are many: i) the proximity to Deception Island and its frequent eruptions; ii) the small catchment area, which means that particles do not have to be transported long distances before they reach the lake; iii) unstable soil conditions and absence of any dense and impeding vegetation; iv) the fact that the lake is fed only by surface run-off from melting snow fields and precipitation; and v) the low chemical stability of the tephra. If the eruptions are frequent enough, these facts may cause a more-or-less continuous inwash of tephra material from the catchment even between eruptions, at least until the catchment soils run out of tephra material or soil erosion decreases significantly. This makes it hard to clearly distinguish any other environmental/ climatic signal, but the RDA plots (Figs. 16 and 17) show that different signals are detectable. We try here to depict what we think the data set tells us about the development of the lake and the nearby region, and the two RDA plots will be very useful tools to illustrate this.

The testing of different response variables as being explanatory environmental variables made 9 of the 21 variables into environmental variables. Based on the assumptions made in the method and result sections above, they mainly represent the environmental factors shown in Tables 5 and 6 and Figs 16 and 17. It should be noted that both the strength and type of environmental indicator that the variable represents often change, when the tephra periods are excluded. In this context it should, however, also be pointed out that e.g. accumulation of lichen spores and carbon inter- 


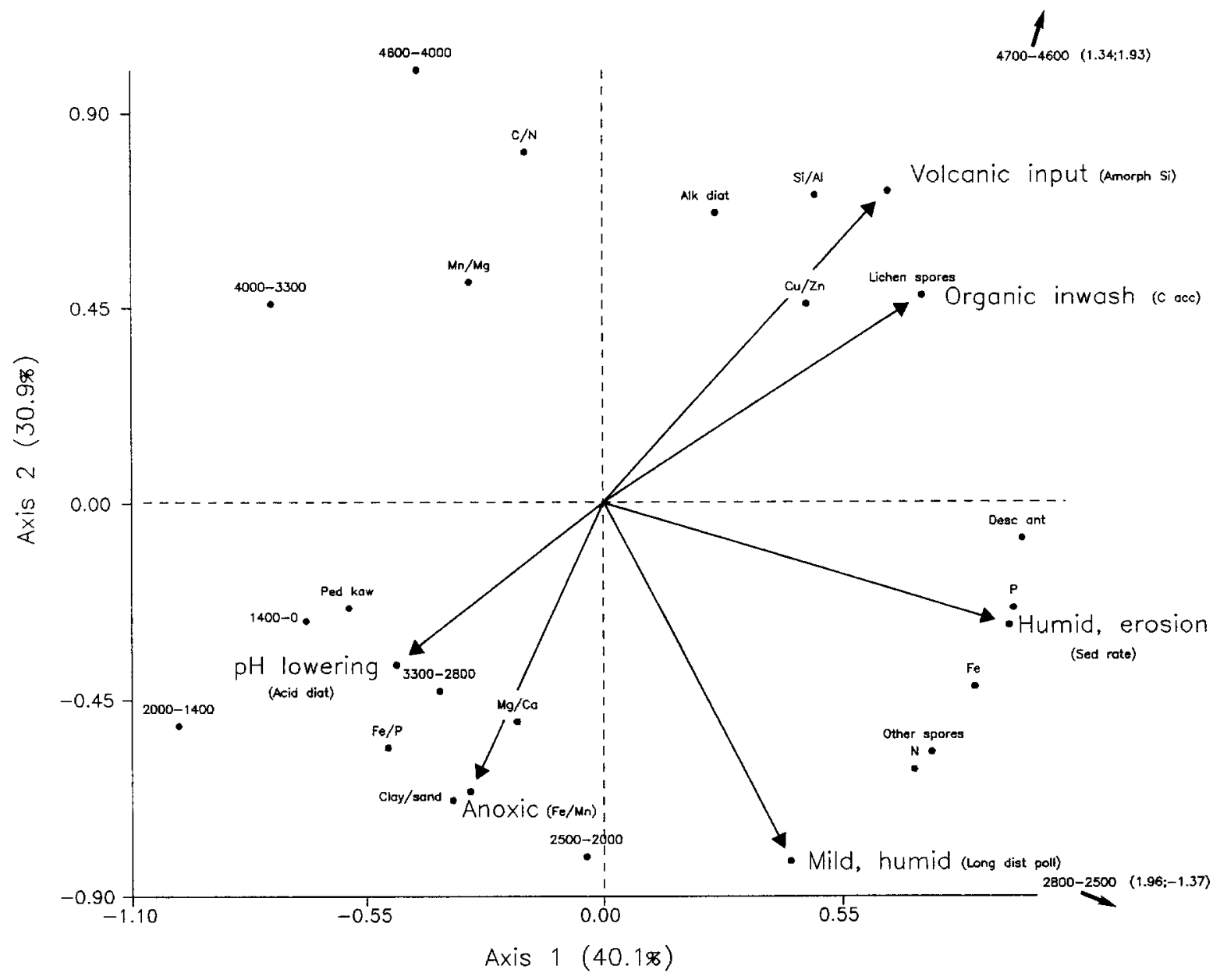

Fig. 16. Redundancy analysis (RDA) of the 8 different time periods with 6 of the 21 variables chosen as predictor explanatory environmental variables. The plot is based on the biplot scores of the environmental variables, the 'species' (response variables) plot, and the linear combination sample scores. The environmental 'arrows' are drawn to the biplot scores of the environmental variables. For further information see text and Tables 5 and 6.

act perfectly in both plots, which is good evidence for the assumption that carbon accumulation mainly reflects organic allochthonous matter. In the environmental-climatic reconstruction below both plots will be used as well as the raw data.

\section{The oldest sediments}

The bottom sediments consist of pure mineral matter and they may be interpreted in different ways. Either they are deglacial deposits or the corings were stopped by a thick impenetrable tephra layer that covers even older sediments. Mat- thies et al. (1990) found a tephra layer on King George Island that they dated to $c a$. 5000 BP. The fact that no till-like deposit, but mainly sandy/silty often tephra-rich sediments, has been found in the bottom of any of the six cored lakes on this part of Byers Peninsula supports this idea. However, the pure minerogenic, tephra-poor silt in the bottom (layer 29 in Table 1), and the extremely low organic carbon content in the following layers may, however, suggest that the lake gradually changed with postglacial conditions. So until other observations are available we regard layer 29 as having been deposited rather soon 


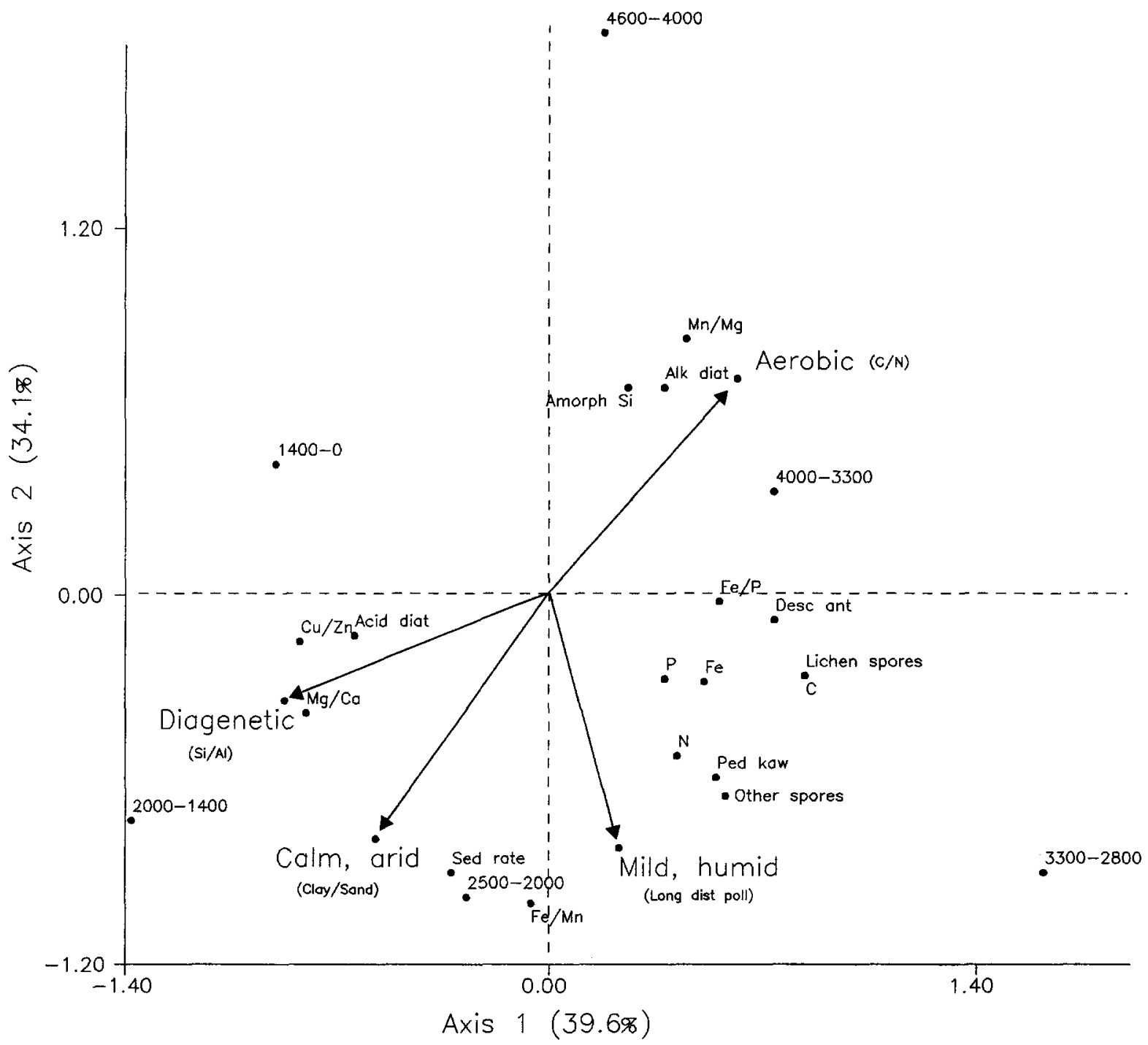

Fig. 17. RDA of six of the time periods (excl. the tephra dominated periods) with 4 of the 21 variables chosen as environmental variables. See Fig. 16.

after deglaciation, which implies that 'Lake Åsa' was deglaciated $\mathrm{ca}$. $5000 \mathrm{BP}$, i.e. 1000 years before Midge Lake is supposed to have become ice-free (Björck et al. 1991a). This is not unlikely, since 'Lake Åsa' is situated farthest away from the Rotch Dome and very close to the deglaciation sea level (Hjort et al. 1992) and a calving ice-margin, while Midge Lake lies on the upper platform with a possibly later deglaciation. Layer 28 is a tephra horizon, AP14, dated to $c a .4700$ BP (Björck et al. 1991b).
4700-4600 BP

The diatom assemblage between 4700 and 4600 BP (low frequencies of 'Fragilaria' sensu Hustedt) suggests that 'Lake Åsa', which today is more of a pond than a lake, in its initial stage was not only deeper, but also larger than today. Today's outlet stream partly flows through some small, narrow ravines, and before these were eroded the lake must have been larger than today. In fact, the diatom data suggest that it might have taken $c a$. 
100 years before today's very small lake was established. The large availability of amorphous $\mathrm{Si}$ compounds in the tephras might also have favored some species. This first part of the lakes' history seems to have been characterised mainly by substantial inwash of volcanic and organic material from highly unstable soils generating bad light conditions for Pediastrum colonies. The abundance of alkaliphilous diatoms and taxa that may be found in soils and mosses also suggests soil erosion. Although the organic $\mathrm{C}$ content, and possibly also the lake productivity, is extremely low in the oldest sediments analysed (layers 2928 ), it is noteworthy that life appears both in the lake (diatoms) as well as around the basin (e.g. lichens and mosses) from almost the very beginning of the sedimentation. The diversity of the spores found is surprisingly high already in the lowermost samples. This suggests that climate was favorable for many types of life forms from the very beginning. Together with the aerobic conditions and the complete dominance of allochthonous components $(\mathrm{C} / \mathrm{N})$, it implies highly humid and mild conditions.

\section{$4600-4000 \mathrm{BP}$}

Between 4600 and $4300 \mathrm{BP}$ the pioneers for low water level Punctastriata pinnata var. lancettula are abundant, followed by another high abundance of Achnanthes species. 'Fragilaria' (sensu Hustedt) are indicators of low water-level (Digerfeldt, 1972); they are known to live in the littoral zone. Haworth (1976) stated that they are the first colonizers of recent deglaciated lakes, the 'pioneers'. The overall increasing frequency of alkaliphilous diatoms may also indicate an increased nutrient supply to the lake. However, the conditions in the lake gradually became calmer and more stable, although the allochtonous input of material, especially tephra, still influenced the sediments. Not until ca. 4300 BP were conditions favorable enough for growth of Pediastrum colonies, which suggests better light conditions with calmer sedimentation. Aerobic conditions still prevailed, but the moderate sedimentation rates indicate that precipitation and thus surface runoff had decreased. Climate was possibly less mild and humid than during the previous period.

4000-3300 BP

This period is characterised by a more uniform diatom flora (zone 3a) than during the following, more 'chaotic', period. The appearance of Stauroneis - a strongly silicified diatom - may indicate high availability of $\mathrm{Si}$. Otherwise this period shows increasing organic $\mathrm{C}$ accumulation, fairly high influx values of pollen grains and spores, high influx values of Pediastrum kawraiskyi, and moderate sedimentation rates $(0.3-0.5 \mathrm{~mm} / \mathrm{yr})$. It is interesting to note that accumulation rates began to increase at $3800 \mathrm{BP}$, perhaps as a combined effect of increased humidity/organic production in the lake. In general this period appears to have been characterised by a gradual warming (Fig. 17) with increasing lake productivity, favorable conditions for Pediastrum growth, and an increased plant diversity around the lake. For the first time there is also a noticeable influx of assumed long distance transported South American pollen grains (cf. Kappen \& Straka 1988), such as e.g. Nothofagus, Ulmaceae, and Chenopodiaceae. This suggests an increasing influence of warmer, and possibly also more humid air-masses from the north/northwest, although the allochthonous components (Fig. 16) suggest very moderate inwash from the catchment.

\section{$3300-2800 B P$}

The diatom assemblage during this and the following time period (diatom zone $3 b$ ) is very mixed. The appearance of Synedra, Amphora, Anomoeoneis, Pinnularia, and Caloneis species, some of these indicated as acidophilous forms by Charles (1985) and Winkler (1985) but as indifferent by others, together with the high input of euterrestrial/terrestrial/aerophilous diatoms suggest not only a fresh supply of nutrients, but also chemical changes related to e.g. climatic/erosional 
changes. The influx values of spores and pollen (incl. long distance transported) increased and influx of Pediastrum colonies reached maximum values. Organic $\mathrm{C}$ attained maximum values of $2.5-3 \%$ and sedimentation rates increased gradually from 0.5 to $0.9 \mathrm{~mm} / \mathrm{yr}$. Although the sediments were quite fine grained, the rather abrupt appearance of terrestrial moss remains at ca. $\mathbf{3 3 0 0}$ BP indicate significant soil erosion. We think that our data suggest that the previous warming trend was accelerated during this period (Fig. 17), although the allochthonous components would become much more dominant in the following period (Fig. 16). Therefore the $\mathrm{C} / \mathrm{N}$ peak (Fig. 6) in the beginning of this period is more an implication of well oxygenated conditions (long ice-free summers) than of allochthonous input. The increasing accumulation rates were probably the result of increased lake productivity/precipitation. The possibly high precipitation, and thus increased soil erosion/surface run-off, however, did not affect the light conditions in the lake water to make it unfavorable for Pediastrum until ca. 2900 BP when the influx of Pediastrum colonies decreased from more than 1000 colonies $/ \mathrm{cm}^{2} / \mathrm{yr}$ to almost zero (Fig. 14). Together with a marked C peak (Fig. 6), we think this shows that optimum mild and humid conditions were reached 2900$2800 \mathrm{BP}$.

\section{$2800-2500 \mathrm{BP}$}

This time period is characterised by a combination of humid/mild and volcanic/allochthonous components (Fig. 16). The latter influence seems to be very dominating, which makes it hard to distinguish the true strength of the climatic variables. The reason for this strong volcanic influence is obviously the impact of the three tephra horizons, AP12-10, dated to 2760-2630 BP (Table 2), of which AP12 possibly played the largest role. The inwash of volcanic matter reached distinct peak values and it is noteworthy that the same can be said about the influx of C (Fig. 6), long distance pollen grains, Deschampsia antarctica, lichen spores, moss spores as well as other spores (Figs. 14 and 16). The opposite can be said about Pediastrum, which more-or-less seems to have disappeared, possibly as an effect of extremely deteriorated light conditions in the water due to a high suspension load in the water during the short, mild growing season. We interpret this rather dramatic phase of the lakes' history as a period characterized by more-or-less primary tephra deposition (either falling directly into the lake water or on the lake ice) and extensive soil erosion. The basic prerequisites for this ca. 300 year long period with vast soil erosion and markedly increased sedimentation rates were certainly triggered by the tephra deposition in the catchment and a substantial surface run-off. Although one should not exclude the possibility of occassional eolian input, we think the data in general suggest high precipitation rates and thus also a possibly fairly mild climate. The extremely high influx values of many of the climatic variables (Figs. 14 and 16) were, however, most likely caused by intense soil erosion, redeposition, and inwash to the lake. This makes it difficult to compare the strength of the climatic variables with those of the previous period, but there are subtle indications in the data set that suggest that the peak of the optimum mild/humid climate might have been reached slightly before AP12 was deposited.

\section{$2500-2000 B P$}

The diatom assemblage suggests that the conditions in the lake were more stable compared to the preceding zone. The more stable values of the epiphytic flora may indicate relatively lower water levels. The increase of acidophilous diatoms at $2500 \mathrm{BP}$ indicate a gradually lowered $\mathrm{pH}$. This period is in general characterized by calm, possibly periodically anoxic conditions in the lake (Figs. 16 and 17). All allochthonous/erosional variables decreased markedly compared to all previous periods, suggesting that precipitation decreased significantly. The greatly reduced influx of spores from the surroundings during this time may indicate both less plant cover and reduced 
precipitation. The return of Pediastrum colonies also implies generally calmer conditions, although the highly variable values, in spite of decreasing sedimentation/clearer water, may suggest that the ice-cover season often was too long for green algae production. This was possibly a result of colder winters and perhaps also colder summers as well as a more arid climate in general. The anoxic influence on this period (Fig. 16) also supports such an interpretation.

\section{0-1400 BP}

The diatom assemblage remained more or less the same with a gradual but slow increase of acidophilous taxa. According to the RDA plots this period was not only characterised by lowered $\mathrm{pH}$, but also by calm, anoxic and diagenetic conditions in the lake, implying that the lake periodically never became ice-free in summer. This suggests that the arid, cold climate described from the previous period might have reached its optimum conditions. There are, however, indications (Figs. 6 and 14) that the last ca. 100 years of this phase was characterised by a more humid/milder climate.

\section{0-0 BP}

This is actually the period that contains the most tephra layers (Table 2), but this fact is only vaguely displayed in Figs 16 and 17. Although the very onset of this last phase in the lakes' history is characterized by tephras, nothing dramatic occurs comparable to the two previous tephra periods. The diatom assemblage in the uppermost part (zone 5) implies an increased input of nutrients (possibly from the tephra), while at the same time the amount of acidophilous forms reach their highest values (Fig. 10). The volcanic influence is also evident by e.g. the increasing sedimentation rates (Fig. 5) and grain-sizes (Fig. 6), and rising accumulations of amorphous Si (Fig. 8). This restricted impact from the tephra fall-outs clearly implies that the tephras alone cannot create the distinct signals occurring around $2700 \mathrm{BP}$ without an efficient agent, such as e.g. soil erosion. There are, however, signs that can be interpreted as reflecting a minor climatic warming: increased aerobic conditions ( $\mathrm{C} / \mathrm{N}$ in Figs. 6 and 17) and increased accumulation of both $\mathrm{N}$ and $\mathrm{C}$. The latter is usually interpreted as an organic allochthonous component (Fig. 16), but in contrast to the other periods the increase in $\mathrm{C}$ is not accompanied by an increase in influx of lichen spores. This may suggest that parts of the $C$ increase was caused by rising lake productivity as an effect of slightly milder summers. The diagenetic/lowered $\mathrm{pH}$ conditions have, however, been maintained or even increased (Figs. 7, 8, and 17), which implies long ice-cover seasons and thus cold winters. This increase may also partly be attributed to the shallowing and an occasional bottom-freezing of the lake. Bottom-freezing does, however, not seem to seriously disturb the sediments. This is confirmed by the ${ }^{210} \mathrm{~Pb}$ and ${ }^{137} \mathrm{Cs}$ profiles. Although no chemical analyses (except $\mathrm{C}$ and $\mathrm{N}$ ) could be carried out on the surface sample, much of the other data (e.g. Fig. 14) implies that the modern climate is milder than during the preceding 2500 years.

\section{Palaeoclimatic conclusions and correlations}

In spite of the problems with the tephra 'noise', we think we have illustrated the possibility to trace climatic signals if a wide variety of stratigraphic variables are used. In this part of Antarctica the tephra does, however, put restrictions on how detailed the climatic reconstructions can become. It is questionable whether a more detailed reconstruction of the terrestrial/limnic development can presently be obtained in an environment so influenced by tephra fall-outs. The planned diatom/ water chemistry data-set for Antarctica (Viv Jones; pers. comm.) could, however, become a further useful tool in evaluating past climatic/ environmental changes.

The studies of 'Lake Åsa' have thus resulted in a palaeoclimatic reconstruction of the last 5000 years. A tentative relative temperature/humidity curve has been drawn to illustrate these changes 
through time (Fig. 18). Comparisons with studies in nearby areas show some striking similarities, but also a few anomalies. The climatic optimum around 3000 BP seems to be a general phenomenon, although expressed in slightly different ways. While several lakes on Byers Peninsula (Midge Lake, 'Lake Åsa' and several other unpublished lakes) all show signs of extensive soil erosion with very large allochthonous inputs, nothing very dramatic is noticed on the neigbouring King George Island, according to Mäusbacher et al. (1989). There the humid climate instead seems to have caused significant glacier advances (Fig. 18). However, Schmidt et al.'s (1990) lake sediment studies on the same island indicate a climatic change between 4700-3200 BP expressed by increased erosion and allochthonous input as well as by increased sedimentation rates.
In general Schmidt et al.'s (1990) conclusions roughly coincide with our palaeoclimatic picture, but to compare our data with other type of records we only present the slightly different picture obtained by Mäusbacher et al. (1989) in Fig. 18. There is also a very distinct climatic signal at 3000 BP in the moss bank on Elephant Island. Apart from the good correspondence on the $3000 \mathrm{BP}$ climatic optimum there also seems to be a fairly good agreement between 'Lake Åsa' and King George Island around $4500 \mathrm{BP}$, with indications of intense soil erosion (cf. Schmidt et al. 1990). This signal is, however, not seen from Elephant Island. This might be due to problems in interpreting the lowermost parts of the moss stratigraphy. When the Antarctic records are compared with similar records in Patagonia and Tierra del Fuego, southernmost South America, there are

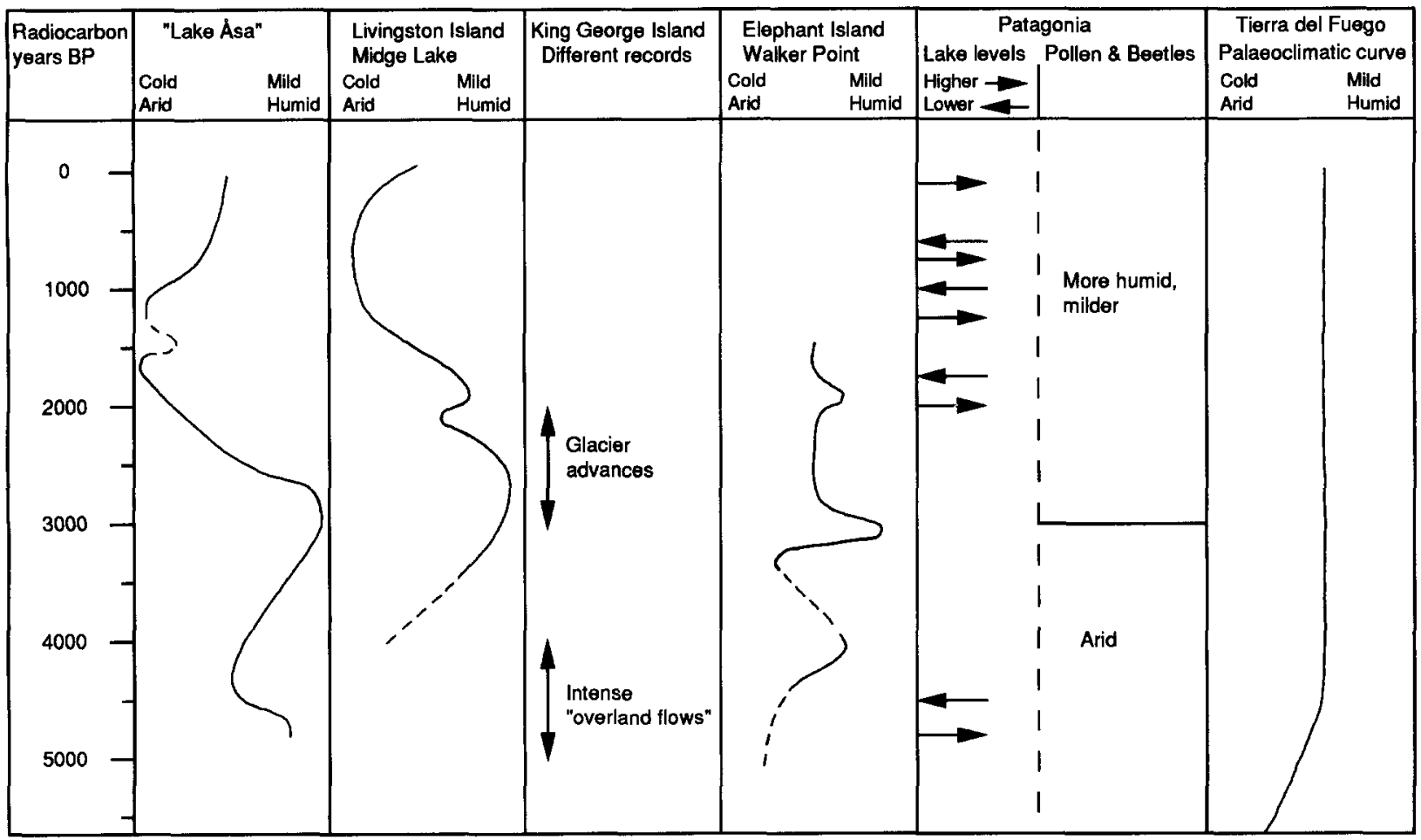

Fig. 18. A diagram summarizing the climatic development in 'Lake Åsa' with modern conditions regarded as 'mean' conditions, on the neighbouring King George Island (Mäusbacher et al., 1989), Midge Lake (Fig. 2) on Byers Peninsula (Björck et al., 1991a), the Walker Point moss bank (Björck et al., 1991c) on Elephant Island (Fig. 1), and palaeoclimatic studies in Patagonia-Tierra del Fuego, southernmost South America. Lake levels are based on Lake Cardiel (Stine \& Stine, 1990), pollen and beetles data are from the Chilean Channels (Ashworth et al., 1991), and the Tierra del Fuego curve is from Markgraf (1989). 
both similarities and anomalies between the regions. The difficulty with the South American records is that they vary greatly altitudinally as well as along longitudinal and latitudinal gradients. For instance, Markgraf (1989) states that the climate in general became more humid and warm between 6000 and 4500 BP in Tierra del Fuego, and has stayed approximately the same ever since, with a minor warming peak at 3000 BP. Further north, lake levels in Lake Cardiel (Stine \& Stine, 1990) have fluctuated greatly during the Holocene, especially in the earliest part. The last larger lake level rise seem to have occurred at $c a$. $5000 \mathrm{BP}$ followed by dry conditions (Stine \& Stine, 1990), and Ashworth et al. (1991) depict arid conditions in the Chilean Channel up to 3000 BP. These differences may imply a latitudinal gradient, since the Antarctic records are more in line with the Tierra del Fuego records (Fig. 18).

The correspondence between the different South Shetland Island records is also fairly good during the last 2500-3000 years. The brief oscillations at $2000 \mathrm{BP}$ in Midge Lake and at Walker Point (Fig. 18) may either be too short to be seen in 'Lake Åsa', be local, non-climatically derived events or erroneous interpretations of the Midge Lake and Walker Point data. In general, however, the last 2500 years have been characterized by more stable conditions with possibly minor oscillations that are difficult to detect in the records. This picture fits well with how Markgraf (1989, 1991) describes the last 3000 years in Patagonia, although the pollen and beetle records from e.g. the Chilean Channel (Ashworth et al., 1991) show that these last millenia were mild and humid.

The rather contrasting Holocene climatic histories of the South Shetland Islands-Tierra del Fuego and central Patagonia may demonstrate latitudinal shifts of the westerly stormtracks through time. In the South Shetland Islands these shifts may generate the continental/maritime climate oscillations that seem to characterize its terrestrial/limnic records (Fig. 18).

Climatic oscillations in Antarctic Holocene records are inherently more subtle than the large glacial/interglacial fluctuations recorded in e.g.
Antarctic ice cores. Detailed analyses of these cores have, however, revealed apparent climatic signals during the Holocene (e.g. Jouzel et al., 1989; Raisbeck et al., 1987). The distance between the Byrd site (Johnsen et al., 1972) in the center of the West Antarctic Ice Sheet and the South Shetland Islands in maritime Antarctica is not only large $(2500 \mathrm{~km})$, but do also represent two completely different climatic regimes. It is interesting that, in spite of this, the Byrd core as well as the $1500 \mathrm{~km}$ further away situated Vostok and Dome C cores (Jouzel et al., 1989) display the most distinct Holocene temperature increase between $c a$. 5000-3000 yr BP. Since this time scale is regarded as a calendar year chronology, it corresponds strikingly well to the temperature/ humidity increase registered in 'Lake Åsa' between ca. 4000 and $2700{ }^{14} \mathrm{C}$ yr BP (Fig. 18). The ${ }^{10} \mathrm{Be}$ concentration record from Vostok (Raisbeck. et al., 1987) does also imply a distinct peak in precipitation at $c a .3000 \mathrm{yr} \mathrm{BP}$, which at least in time corresponds to the humidity peak on Livingston Island. This precipitation peak is succeeded by rapidly declining precipitation (cf. 'Lake Åsa'). Although these correlations between the most maritime and most continental parts of Antarctica are attractive enough, they should only be regarded as exciting speculations on continental scale climatic changes in Antarctica during Late Holocene. It is, however, fascinating that the same climatic signal may be registered in the precipitation of the huge Antarctic Ice Cap as well as in small ponds and lakes of the South Shetland Islands.

\section{Acknowledgements}

The field work in 'Lake Åsa' was carried out by SB together with Anders Wasell during the SWEDARP 1988/89 expedition. The pilots and crew on board M/S Stena Arctica put us ashore. Göran Skog and Kerstin Lundahl carried out the ${ }^{14} \mathrm{C}$ dating. Cynan Ellis-Evans provided us with aerial photographs, and Viv Jones provided the water chemical analyses. Arne Thell helped us to identify the supposed lichen spores and Lars Hedenäs 
the supposed moss spores. Torbjörn Willén gave information about Pediastrum, Jeronimo Lopez Martinez provided us with a preliminary topographic map and John Birks gave us the final invaluable advice about multivariate analyses. To all these people we are very grateful. Many valuable discussions with Gunnar Digerfeldt are also acknowledged. This work was financed by the Swedish Polar Secretariat and above all, The Swedish Natural Science Research Council (NFR).

\section{Appendix 1}

List of all diatoms present in the core from 'Lake Åsa'. Those which are considered to be aerophilic, eu-terrestic, bryophytic are marked by an asterisk (the literature used is given in the text).

Achnanthes cf. affinis Grunow

*A. conspicua Mayer

*A. exigua Grun.

A. germainii Manguin

A. groenlandia (Cleve) Grunow

A. cf. kryophila Petersen

*A. lanceolata (Bréb.) Grunow var. lanceolata

*A. lanceolata var. elliptica Cleve

*A. lanceolata ssp. or var. 'frequentissima' sensu Lange-Bertalot \& Krammer (1989)

A. linkei Hust./delicatula (Kützing) Grunow

*A. minutissima Kützing

${ }^{*} A$, mollis Krasske

*A. pusilla (Grunow) De Toni

*A. renei Lange-Bertalot \& Schmidt

*A. subatomoides (Hust.) Lange-Bertalot \& Archibald

A. spp

Amphora veneta Kützing

*Anomoeoneis minor Krasske

Aulacoseira cf. italica (Ehr.) Simonsen

* Caloneis bacillum (Grunow) Cleve

${ }^{*}$ C. tenuis (Gregory) Krammer

* Diadesmis contenta (Grunow) D.G. Mann fo. contenta

${ }^{*} D$. contenta fo. biceps (Arnott) D.G. Mann

Fallacia cf. naumannii (Hust.) D.G. Mann

Fragilaria cf. capucina Desz.

$F$. crotonensis Kitton

F. vaucheriae (Kütz.) Petersen

Fragilariformis virescens (Ralfs) Williams \& Round

*Gomphonema angustatum (Kütz.) Rabenhorst

${ }^{*} G$. gracilis Ehrenberg

${ }^{*} G$. intricatum Kützing

${ }^{*} G$. parvulum (Kütz.) Kützing
G. spp

*Hantzschia amphioxys (Ehr.) Grunow

* Luticola cohnii (Hilse) D.G. Mann

* Melosira roseana Rabenhorst

* Navicula capitata Ehrenberg var. capitata

*N. capitata var. hungarica (Grunow) Ross

$N$. cuspidata (Kütz.) Kützing

$* N$. elginensis (Gregory) Ralfs

$N$. explanata Hustedt

*N. festiva Krasske

*N. gibbula Cleve

$N$. glaciei Van Heurck

${ }^{*} N$. gregaria Kützing

* $N$. tabellariaeformis Krasske

$N$. veneta Kützing

$N$. spp

*Nitzschia cf. debilis (Arnott) Grunow

*N. frustulum (Kütz.) Grunow

* $N$. cf. hantzschiana Rabenhorst

$N$. homburgensis Lange-Bertalot

$N$. laevis Hustedt

$N$. levidensis (W. Smith) Grunow

$N$. palea (Kütz.) W. Smith

$N$. paleacea Grunow

N. perminuta (Grunow) M. Peragallo

$N . \operatorname{spp}$

* Pinnularia borealis Ehrenberg

${ }^{*} P$. divergens $\mathrm{W}$. Smith

*P. gibba Ehrenberg var. gibba

*P. gibba var. linearis Hustedt

$P$. ignobilis (Krasske) Cleve-Euler

*P. microstauron (Ehrenbg.) Cleve var. microstauron

*P. microstauron var. brebissonii (Kütz.) Mayer

${ }^{*} P$. cf. obscura Krasske

$P$. sibirica Cleve

*P. subcapitata Gregory

${ }^{*} P$. viridis (Nitzsch) Ehrenberg

$P$. spp

Pseudostaurosira brevistriata (Grun.) Williams \& Round

Punctastriata pinnata var. lancettula (Schuman) Williams \& Round

* Sellaphora bacillum (Ehrenbg.) D.G. Mann

S. disjuncta (Hust.) D.G. Mann

*S. pupula (Kütz.) D.G. Mann

*S. seminulum (Grun.) D.G. Mann var. seminulum

${ }^{*}$ S. seminulum var. intermedia (Hust.) D.G. Mann

Stauroneis agrestis Petersen

* S. anceps Ehrenberg var. anceps

${ }^{*} S$. anceps var. hyalina Brun et Peragallo

$S$. anceps fo. gracilis Rabenhorst

${ }^{*} S$. phoenicenteron (Nitzsch) Ehrenbg.

$S$. cf. producta Grunow

S. spp

Synedra rumpens Kütz. var. rumpens

* $S$. rumpens var. familaris (Ehrenbg.) Rabenhorst

$S$. spp 


\section{References}

Andrews, G.W., 1981. Achnanthes linkei and the origin of monoraphid diatoms. Bacillaria 4: 29-40.

April, R.H. \& D.M. Keller, 1992. Saponite and vermiculite in amygdales of the Granby basaltic tuff, Connecticut Valley. Clays and Clay Minerals 40.1: 22-31.

Ashworth, A.C., V. Markgraf, \& C. Villagran, 1991. Late Quaternary climatic history of the Chilean Channels based on fossil pollen and beetle analyses, with an analysis of the modern vegetation and pollen rain. J. Quat. Sci. 6: 279291.

Barsch, D. \& R. Mäusbacher, 1986. New data on the relief development of the South Shetland Islands, Antaretica. Interdisciplinary Science Review 11 (2): 211-218.

Beger, H., 1927. Beiträge zur Ökologie und Soziologie der luftlebigen (atmosphytischen) Kieselalgen. Ber. Deutsch. Bot. Ges. 45: 385-407.

Berglund, B.E. \& M. Ralska-Jasiewiczowa, 1987. Pollen analysis and pollen diagrams. In Berglund, B.E. (ed.): Handbook of Holocene Palaeoecology and Palaeohydrology. John Wiley \& Sons, Chicester: 455-484.

Berner, R.A., 1971. Principles of chemical sedimentology. McGraw-Hill, 240 pp.

Berner, R.A., 1981. Authigenic mineral formation resulting from organic matter decomposition in modern sediments. Fortsch. Min. 59: 117-135.

Bernhardt, H., J. Clasen \& E.A. Nusch, 1970. Vergleichende Untersuchungen zur Ermittlung der Eutrophierungsvorgänge und ihrer Ursachen and Riveris- und Wahnbachtalsperre. Abschlussbericht 1968-1970. Forschungsvorhaben Wasser 3/68.

Birkenmajer, K., 1981. Raised marine features and glacial history in the vicinity of Arctowski Station, King George Island (South Shetland Islands, West Antarctica). Bulletin of the Polish Academy of Sciences, Serie Science de la Terre 29: 109-117.

Birkenmajer, K., R. Ochyra, I.U. Olsson, \& L. Stuchlik, L., 1985. Mid-Holocene Radiocarbon-dated Peat at Admiralty Bay, King George Island (South Shetland Islands, West Antarctica). Bulletin of the Polish Academy of Sciences, Earth Sciences 33: 7-12.

Björck, S., P. Sandgren, \& R. Zale, 1991b. Late Holocene Tephrochronology of the Northern Antarctic Peninsula. Quat. Res. 36: 322-328.

Björck, S., C. Hjort, O. Ingólfsson, \& G. Skog, 1991d. Radiocarbon dates from the Antarctic Peninsula - problems and potential. In J.J. Lowe (ed.), Radiocarbon Dating: Recent Applications and Future Potential. Quaternary Proceedings 1, Quaternary Research Association. Cambridge: $55-65$.

Björck, S., H. Håkansson, R. Zale, W. Karlén, \& B. Liedberg Jönsson, 1991a: A late Holocene lake sediment sequence from Livingston Island, South Shetland Islands, with palaeoclimatic implications. Antarctic Science 3: 61-72.

Björck, S., N. Malmer, C. Hjort, P. Sandgren, O. Ingólfsson,
B. Wallén, R.I. Lewis Smith, \& B. Liedberg Jönsson, 1991c. Stratigraphic and paleoclimatic studies of a 5500-year-old moss bank on Elephant Island, Antarctica. Arctic and Alpine Research 23: 361-374.

Blümel, D.W., R. Emmerman \& W. Smykatz-Kloss, 1985. Vorkommen und Entstehung von trioktaedrischen Smektiten in den Basalten und Böden der Konig-Georg-Insel (S-Shetlands/West-Antarktis). Polarforschung 55,1: 3348.

Bock, W., 1963., Diatomeen extrem trockener Standorte. Nova Hedwigia 5: 199- 247.

Boström, K. 1967. Some pH-controlling Redox Reactions in Natural Waters. Advances in Chemistry Series 67: 286311.

Bourelley, P. \& E. Manguin, 1954. Contribution à la flore algale d'eau douce des Iles Kerguelen. Mémoires de l'Institute Scientifique de Madagascar 5: 7-56.

Brendemühl, J., 1950. Über die Verbreitung der Erddiatomeen. Arch. Mikrobiol. 14: 407-449.

British Antarctic Survey, 1979. British Antarctic Territory, Geological Map. Series BAS 500, Sheet 2, Edition 1.

Brown, G., 1980. Associated Minerals. In Brindley, G.W.\& Brown, G. (eds): Crystal Structures of Clay Minerals and their X-ray Identification. Mineralogical Society, London: $361-410$.

Brown, G. \& G.W. Brindley, 1980. X-ray Diffraction Procedures for Clay Mineral Identification. In Brindley, G.W. \& Brown, G. (eds): Crystal Structures of Clay Minerals and their X-ray Identification. Mineralogical Society, London: 305-359.

Carlsson, G.W.F., 1913. Süsswasser-Algen aus der Antarktis, Süd-Georgien und der Falkland Inseln. Wiss. Ergebn. der Schwedischen Südpolar Exp. 1901-1903, 4/14: 1-94.

Charles, D.F., 1985. Relationship between surface sediment diatom assemblages and lakewater characteristics in $\mathrm{Ad}$ irondack Lakes. Ecology 66 (3): 994-1011.

Chester, R. \& M.J. Hughes, 1967. A chemical technique for the separation of ferro-manganese minerals, carbonate minerals and adsorbed trace elements from pelagic sediments. Chem. Geol. 2: 249-262.

Clapperton, C.M. \& D.E. Sugden, 1980. Geomorphology of the St. Andrews Bay-Royal Bay area, South Georgia. British Antarctic Survey Miscellaneous Map Series, Sheet 1.

Cleve, P.T., 1894-95. Synopsis of the naviculoid diatoms. Kungl. Sv. Vet. Akad. Handl. I, 26: 1-194; II, 27: 1-219.

Cleve-Euler. A., 1951-1955. Die Diatomeen von Schweden und Finnland. Kungl. Sv. Vet.Akad. Handl. 4, 2:l (1951): $1-163$; $3: 3$ (1952): 1-153; 4:1 (1953): 1-255; $4: 5$ (1953): 1-158; 5:4 (1955): 1-232.

Cholnoky, B.J., 1968. Die Ökologie der Diatomeen in Binnengewässern. Lehre, $699 \mathrm{pp}$.

Curtis, C.D., M.L. Coleman \& L.G. Love, 1986. Pore water evolution during sediment burial from isotopic and mineral chemistry of calcite, dolomite and siderite concretions. Geochim. Cosmochim. Acta 50: 2321-2334.

Digerfeldt, G., 1972. The Post-Glacial development of Lake 
Trummen. Regional vegetation history, water level changes and palaeolimnology. Folia Limn. Scand. 16: $96 \mathrm{pp}$.

Digerfeldt, G., 1988. Reconstruction and regional correlation of Holocene lake-level fluctuations in Lake Bysjön, South Sweden. Boreas 17: 165-182.

Drever, J.I., 1973. The preparation of oriented clay mineral specimens for X-ray diffraction analysis by a filtermembrane peel technique. Am. Miner. 58: 553-554.

Engstrom, D.R. \& H.E. Wright Jr, 1984. Chemical stratygraphy of lake sediments as a record of environmental change. In Haworth, E.Y. \& J.W.G. Lund (eds): Lake Sediments and Environmental History. Leicester University Press: 11-68.

Engstrom, D.R., E.B. Swain \& J. Kingston, 1985. A palaeolimnological record of human disturbance from Harvey's Lake, Vermont: geochemistry, pigments, and diatoms. Freshwat. Biol. 15: 261-288.

Foged, N., 1980. Diatoms on Öland, Sweden. Bibliotheca Phycologica, 49: 1-98. Foged, N., 1982. Diatoms in Bornholm, Denmark. Bibliotheca Phycologica, 59: 1-175.

Florin, M.-B., 1970. Late-glacial diatoms of Kirchner Marsh, S.E. Minnesota. Nova Hedwigia 31: 667-756.

Garrels, R.M. \& Ch. L. Christ, 1965. Solutions, Minerals and Equilibria. Harper \& Row, N.Y. 450 pp.

Håkansson, H., 1984. The recent diatom succession of Lake Havgårdssjön, South Sweden. In: Proceedings of the 7th Symposium in fossil and recent diatoms, Philadelphia 1982: 411-429.

Hansen, K., 1959. Sediments from Danish lakes. J. Sedim. Petrol. 29, 38-46.

Hansson, L.-A. \& H. Håkansson, 1992. Diatom community response along a productivity gradient of shallow Antarctic lakes. Polar Biol. 12: 463-468.

Haworth, E.Y., 1976. Two Late Glacial (Late Devensian) diatom assemblage profiles from Northern Scotland. New Phyt. 77: 227-256.

Hickman, M. \& D. H. Vitt., 1973. The aerial epiphytic diatom flora of moss species from Subantarctic Campbell Island. Nova Hedwigia 24: 443-458.

Hjort, C., O. Ingólfsson \& S. Björck, 1992. The last major deglaciation in the Antarctic Peninsula region - A review of recent Swedish Quaternary research. In Y. Yoshida (ed.), Recent progress in Antarctic Earth Science. Terra Scientific Publishing Company; Tokyo: 000-000.

Hobbs, G.J., 1968., The geology of the South Shetland Islands. IV. The geology of Livingston Island. British Antarctic Survey Scientific Reports 47: 1-34.

Holm, E., 1984: Review of Alpha-Particle Spectrometric Measurements of Actinides. Int. J. Appl. Rad. and Isot. 35 (4): 285-290.

Hustedt, F., 1930-66. Die Kieselalgen Deutschlands, Österreichs und der Schweiz. In: Rabenhorst's Kryptogamenflora von Deutschland, Österreich und der Schweiz, 7. Leipzig.

Hustedt, F., 1934. Die Diatomeenflora von Poggenpohls Moor bei Dotlingen in Oldenburg. Bremer Wiss. Ges. Ab- handl. u. Vorträge Jg 8/9: 362-403. Hustedt, F., 1938/39. Systematische und ökologische Untersuchungen über die Diatomeenflora von Java, Bali und Sumatra. Systematischer Teil (1938), Archiv. Hydrobiol. Suppl. 15:130-506; Allgemeiner Teil (1938) Archiv Hydrobiol. Suppl. 15: 638790; (1939) Suppl. 16: 1-155, 274-394.

Hustedt, F., 1942. Diatomeen aus der Umgebung von Abisko in Schwedisch-Lappland. Arch. Hydrobiol. 39: 82-174.

Hustedt, F., 1957. Dia Diatomeenflora des Flussystems der Weser im Gebiet der Hansestadt Bremen. Abhandlungen, naturw. Verein Bremen 34 (3): 181-440.

Ingólfsson, O., C. Hjort, S. Björck \& R.I. Lewis Smith, 1992. Late Pleistocene and Holocene glacial history of James Ross Island, Antarctica. Boreas 21: 209-222.

Jackson, M.L., 1975. Soil Chemical Analysis - Advanced Course. 2nd edition, 10th Printing. Published by the author, Madison, Wisc. 991 pp.

Janssens, J.A., 1990. Ecology of Peatland Bryophytes and Palaeoenvironmental Reconstruction of Peatlands using Fossil Bryophytes. Methods Manual, Update August 1990. Available from the author.

John, B.S., 1972. Evidence from the South Shetland Islands towards a glacial history of West Antarctica. In D.E. Sugden \& R.J. Price (eds.), Polar Geomorphology, Institute of British Geographers, 75-92.

Johnsen, S.J., W. Dansgaard, H.B. Clausen \& C.C. Langway, 1972. Oxygen isotope profiles through the Antarctic and Greenland ice sheets. Nature 235: 429- 434.

Jouzel, J., G. Raisbeck, J.P. Benoist, F. Yiou, C. Lorius, D. Raynaud, J.R. Petit, N.I. Barkov, Y.S. Korotkevitch \& M. Kotlyakov, 1989. A comparison of deep Antarctic ice cores and their implications for climate between 65,000 and 15,000 years ago. Quat. Res. 31: 135-150.

Jørstad, K., B. Salbu \& E. Roaldset, 1982. Vertical distribution of trace elements in fresh water, saline water and sediments from Lake Rørholtfjorden, Norway. Chem. Geol. 36: $325-347$.

Kappen, L. \& H. Straka, 1988. Pollen and spores transport into the Antarctic. Polar Biology 8: 173-180.

Krammer, K. \& H. Lange-Bertalot, 1986. Süsswasserflora von Mitteleurope. Bacillariophyceae. 1 Teil. Naviculaeae. Stuttgart, New York. Gustav Fischer Verlag. 876 pp.

Krammer, K. \& H. Lange-Bertalot, 1988. Süsswasserflora von Mitteleurope. Bacialliophyceae. 2 Teil. Surirellaceae. Stuttgart, New York. Gustav Fischer Verlag. 596 pp.

Krammer, K. \& H. Lange-Bertalot, 1991a. Bacillariophyceae. 3. Teil: Centrales, Fragilariaceae, Eunotiaceae. In Ettl, H., Gerloff, J., Heynig, H. \& Mollen hauer, D. (eds.): Süsswasserflora von Mitteleuropa. $576 \mathrm{pp}$.

Krammer, K. \& H. Lange-Bertalot, 1991b. Bacillariophyceae. 4. Teil: Achnantha- ceae. Kritische Ergänzungen zu Navicula (Sineolata) und Gomphonema. In Ettl, H., Gerloff, J., Heynig, H. \& Mollenhauer, D. (eds.): Süsswasserflora von Mitteleuropa. $576 \mathrm{pp}$.

Krasske, G., 1932. Beiträge zur Kenntnis der Diatomeenflora der Alpen. Nova Hedwigia 72: 92-134. 
Krasske, G., 1938. Beiträge zur Kenntnis der Diatomeenflora von Island und Spitzbergen. Arch. Hydrobiol. 33: 503-533.

Krasske, G., 1939. Zur Kieselalgenflora Südchiles. Arch. Hydrobiol. (und Planktonkunde) 35: 349-468.

Krausse, G.L., C.L. Schelske \& C.O. Davis, 1983. Comparison of three wet-alkaline methods of digestion of biogenic silica in water. Freshwater Biology 13: 73-81.

Krieger, W., 1933. Die Algen. In Hibzheimer, M. (ed.): Das Naturschutzgebiet Schildow Teil II, Neudamm und Berlin, 55-82.

Lange-Bertalot, H. \& K. Krammer, 1989: Achnanthes, eine Monographie der Gattung mit Definition der Gattung Cocconeis und Nachträgen zu den Naviculaceae. Bibliotheca Diatomologica 18. 393 pp. J. Cramer, Berlin.

Le Cohu, R. \& Maillard, R. 1983. Les diatomées monoraphidées del Iles Kerguelen. Annales Limnologie 19:143167.

Le Cohu, R. \& Maillard, R. 1986. Diatomées monoraphidées del Iles Kerguelen (a l'exclusion des Monoraphidées). Annales Limnologie 22: 99-118.

Lumsden, D.N., L.G. Shipe \& R.V. Lloyd, 1989. Mineralogy and $\mathrm{Mn}$ geochemistry of laboratory-synthesized dolomite. Geochim. Cosmochim. Acta 53: 2325-2329.

Lund, J.W.G., 1945-1946. Observations on soil algae. I. The ecology, size and taxonomy of British soil diatoms. New Phytol. 44: 196-219, (1945); 45: 56- 110, (1946).

Markgraf, V. 1989. Palaeoclimates in Central and South America since $18,000 \mathrm{BP}$ based on pollen and lake-level records. Quat. Sci. Rev. 8: 1-24.

Markgraf, V. 1991. Late Pleistocene environmental and climatic evolution in southern America. Bamberger Geogr. Schr. 11: 271-281.

Matthies, D., R. Mäusbacher \& D. Storzer, 1990. Deception Island tephra: A stratigraphical marker for limnic and marine sediments in Bransfield Strait area. Zentralblatt für Geologie und Paläontologie, Teil 1: 153-165.

Mäusbacher, R. 1991. Die jungquartäre Relief- und Klimageschichte im Bereich der Fildeshalbinsel Sud-ShetlandInseln, Antarktis. Heidelberger Geographische Arbeiten, Heft 89: 207 pp.

Mäusbacher, R., J. Müller, M. Münnich \& R. Schmidt, 1989. Evolution of postglacial sedimentation in Antarctic lakes (King George Island). Zeitschrift für Geomorphologie N. F. 33: 219-234.

McEwan, D.M.C. \& M.J. Wilson, 1980. Interlayer and Intercalation Complexes of Clay Minerals. In Brindley, G.W. \& Brown, G. (eds): Crystal Structures of Clay Minerals and their X-ray Identification. Mineralogical Society, London: 197-248.

Newman, A.C.D. \& G. Brown, 1987. The chemical constitution of clays. In Newman, A.C.D. (ed.): Chemistry of clays and clay minerals. Mineral. Soc. Mon. No. 6. Longman Scientific \& Technical: 1-128.

Oppenheim, D.R., 1990. A preliminary study of benthic diatoms in contrasting lake environments. In Kerry, K.R. \& Hempel, G. (eds). Antarctic Ecosystems. Ecological
Change and Conservation. Springer Verlag, Berlin: 91-99. Oppenheim, D.R. \& R. Greenwood, 1990. Epiphytic diatoms in two freshwater maritime Antarctic lakes. Freshwater Biology 24: 303-314.

Oppenheim, D. \& C. Ellis-Evans, 1989. Depth related changes in benthic diatom assemblages of a maritime Antarctic lake. Polar Biol. 9: 525-532.

Orvig, S., 1970. World Survey of Climatology Volume 14. Climates of the Polar Regions. Elsevier, AmsterdamLondon-New York.

Pankow, H., D. Haendel, W. Richter \& U. Wand., 1987. Algologische Beobachtun gen in der Schirmacher- und Unterseeoase (Dronning-Maud-Land, East Antarctica). Arch. Protistenkunde 134: 59-82.

Patrick R. \& C.W. Reimer, 1966. The diatoms of the United States. Monographs of the Acad. Nat. Sci. Philadelphia, vol. I. Fragilariaceae, Eunotiaceae, Achnanthaceae, Naviculaceae. $688 \mathrm{pp}$.

Patrick, R. \& C.W. Reimer, 1972. The diatoms of the United States. Monograph of the Acad. Nat. Sci. Philadelphia vol. 2. Entomoneidaceae, Cymbellaceae, Gomphonemaceae, Epithemiaceae, 213 pp.

Pennington, W., 1978. Responses of some British lakes to past changes in land use on their catchments. Verh. Internat. Verein. Limnol. 20: 636-641.

Petersen, J. Boye, 1928. The aerial algae of Iceland. The Botany of Iceland 2: 325-447.

Petersen, J. Boye, 1935. Studies on the biology and taxonomy of soil algae. Dansk Bot. Arkiv 8, 183 pp.

Raisbeck, G.M., F. Yiou, D. Bourles, C. Lorius, J. Jouzel \& N. Barkov, 1987. Evidence for two intervals of enhanced ${ }^{10} \mathrm{Be}$ deposition in Antarctic ice during the last glacial period. Nature 326: 273-277.

Renberg, I., 1976. Paleolimnological investigations in Lake Prästsjön. Early Norrland 9: 113-159.

Roos, P., E. Holm \& R.B.R. Persson, A. Aarkrog, \& S.P. Nielsen, 1992. Flux of ${ }^{210} \mathrm{~Pb},{ }^{137} \mathrm{Cs},{ }^{239+240} \mathrm{Pu}$, and ${ }^{241} \mathrm{Am}$ in the Antarctic Peninsula area. Science of the Total Environment, in press.

Round, F.E., 1957. Studies on bottom-living algae in some lakes of the English Lake district. J. Ecol. 45: 133-148.

Round, F.E., 1965. The epipsammon: a relatively unknown freshwater algal association. $\mathrm{Br}$. phycol. Bull. 2(6): 456462.

Round, F.E., 1968. Biologie der Algen. 315 pp. Stuttgart.

Round, F.E., R.M. Crawford \& D.G. Mann, 1990. The diatoms. Biology and morphology of the genera. Cambridge Univ, Press, Cambridge. 747 pp.

Salden, N., 1978. Beiträge zur Ökologie der Diatomeen (Bacillariophyceae) des Süsswassers. Decheniana 22: 1-238.

Schlüter, M., 1961. Zur Bedeutung der litoralen Diatomeen unserer Gewässer. Z. Fischerei 10 NF, 4/5: 351-359.

Schmidt, R., R. Mäusbacher \& J. Müller, 1990. Holocene diatom flora and stratigraphy from sediment cores of two Antarctic lakes (King George Island). J. Paleolimn. 3: 5574. 
Schuster, R.M., 1966. The Hepatiaceae and Anthocerotae of North America, east of the hundredth meridian. Vol. 1. 812 pp. Columbia Univ. Press.

Schwabe, G.H., 1970. Auf Surtsey Island im Sommer nachgearisene nicht marine Algen. Shriften des naturwiss. Vereins für Schleswig-Holstein, Sonderband Surtsey: 31-100.

Simonsen, R., 1962. Untersuchungen zur Systematik und Ökologie der Boden diatomeen der westlichen Ostsee. Internationale Revue der gesamten Hydrobiologie. Systematische Beihefte 1, 1-144.

Stine, S. \& M. Stine, 1990. A record from Lake Cardiel of climate change in southern South America. Nature 345: $705-708$.

Suess, E., 1979. Mineral phases formed in anoxic sediments by microbial decomposition of organic matter. Geochim. Cosmochim. Acta 43: 339-352.

Sugden, D.E. \& C.M. Clapperton, 1986. Glacial history of the Antarctic Peninsula and South Georgia. South African Journal of Science 82: 508-509.

Tatur, A. \& R. del Valle, 1986. Badania paleolimnologicne i geomorfologicne na wyspie krola jerzego-Antarktyka zachodnia (1984-1986). Preglad Geologiczny 11: 621-626.

Ter Braak, C.J.F., 1988. CANOCO - a FORTRAN programme for canonical community ordination by [partial] [detrended][canonical] correspondence analysis, principal component analysis and redundancy analysis (version 2.1). Technical Report, LWA-88-02, 95 pp. Wageningen, Nerherlands.
Ter Braak, C.J.F. \& I.C. Prentice, 1988. A theory of gradient analysis. Adv. Ecol. Res. 18, 271-317.

Troian, F.L., H.C. Fensterseifer \& M.A. Fontoura-Hansen, 1990. Difratometria de raios-x em rochas tufiticas das Peninsulas Fildes (Ilha Rei George) e Stansbury (Ilha Nelson), Shetland do Sul, Antarica. Serie Cientifica Instituto Antártico Chileno 40: 9-19.

Van Heurck, H., 1908. Expedition Antartique Belge. Résultate du Voyage du S.Y. 'Belgia' en 1897-1899. Botanique, Diatomées, 129 pp. J.-E. Buschmann, Anvers.

Warncke, E., 1980. Spring areas: ecology, vegetation, and comments on similarity coefficients applied to plant communities. Holarctic Ecology, vol. 3(4) DISS. 333 pp.

Wasell, A. \& Håkansson, H. 1992. Diatom stratigraphy in a lake on Horseshoe Island, Antarctica: a marine:brackishfresh water transition with comments on the systematics and ecology of the most common diatoms. Diatom Research 7: 157-194.

Weaver, Ch. E., 1989. Clays, Muds, and Shales. Developments in Sedimentology 44. Elsevier, Amsterdam: 819 pp.

Winkler, M.G., 1985. Diatom evidence of environmental changes in wetlands: Cape Cod National Seashore. Center for Climatic Research. Inst. for Env. Studies. Univ, of Madison, Madison.

Zale, R. \& W. Karlén, 1989. Lake sediment cores from the Antarctic Peninsula and surrounding islands. Geogr. Ann. 71A: 211-220. 